University of South Florida

DIGITAL COMMONS

Digital Commons @ University of

@ UNIVERSITY OF SOUTH FLORIDA

South Florida

$3-2018$

\title{
Deciphering the State of the Late Miocene to Early Pliocene Equatorial Pacific
}

\author{
A. J. Drury \\ Imperial College London \\ G. P. Lee \\ Imperial College London \\ W. R. Gray \\ University College London \\ M. Lyle \\ Oregon State University \\ T. Westerhold \\ University of Bremen
}

See next page for additional authors

Follow this and additional works at: https://digitalcommons.usf.edu/msc_facpub

Part of the Life Sciences Commons

\section{Scholar Commons Citation}

Drury, A. J.; Lee, G. P.; Gray, W. R.; Lyle, M.; Westerhold, T.; Shevenell, Amelia E.; and John, C. M., "Deciphering the State of the Late Miocene to Early Pliocene Equatorial Pacific" (2018). Marine Science Faculty Publications. 597.

https://digitalcommons.usf.edu/msc_facpub/597

This Article is brought to you for free and open access by the College of Marine Science at Digital Commons @ University of South Florida. It has been accepted for inclusion in Marine Science Faculty Publications by an authorized administrator of Digital Commons @ University of South Florida. For more information, please contact digitalcommons@usf.edu. 


\section{Authors}

A. J. Drury, G. P. Lee, W. R. Gray, M. Lyle, T. Westerhold, Amelia E. Shevenell, and C. M. John 


\section{Paleoceanography and Paleoclimatology}

\section{RESEARCH ARTICLE \\ 10.1002/2017PA003245 \\ Deciphering the State of the Late Miocene to Early Pliocene Equatorial Pacific}

\author{
Key Points: \\ - First late Miocene-early Pliocene \\ planktic detailed stable isotope and \\ discrete trace element records from \\ equatorial Pacific IODP Site U1338 are \\ presented \\ - Fine fraction-foraminiferal $\delta^{13} \mathrm{C}$ \\ gradients suggest that upwelling \\ (7.1-6.0 and 5.8-4.6 Ma) partially \\ drove the Late Miocene Biogenic \\ Bloom at Site U1338 \\ - The equatorial Pacific was warm \\ between $8.0-6.5$ and $5.2-4.4 \mathrm{Ma}$, with \\ asymmetric thermal gradients and \\ eastern cooling occurring from 6.5 to \\ $5.7 \mathrm{Ma}$
}

Supporting Information:

- Supporting Information S1

- Tables S1-S4

Correspondence to:

A. J. Drury,

ajdrury@marum.de

\section{Citation:}

Drury, A. J., Lee, G. P., Gray, W. R., Lyle, M., Westerhold, T., Shevenell, A. E., \& John, C. M. (2018). Deciphering the state of the late Miocene to early Pliocene equatorial Pacific. Paleoceanography and Paleoclimatology, 33, 246-263. https://doi.org/10.1002/2017PA003245

Received 8 SEP 2017 Accepted 23 JAN 2018 Accepted article online 2 FEB 2018 Published online 11 MAR 2018

\author{
A. J. Drury ${ }^{1,2}$ (D) G. P. Lee ${ }^{1,3}$ iD, W. R. Gray ${ }^{4,5}$ iD, M. Lyle ${ }^{6}$ iD, T. Westerhold² ${ }^{2}$, A. E. Shevenell ${ }^{\text {iD, }}$ \\ and C. M. John' ${ }^{1}$ iD \\ ${ }^{1}$ Department of Earth Science and Engineering, Imperial College London, London, UK, ${ }^{2}$ Now at MARUM - Center for Marine \\ Environmental Sciences, University of Bremen, Bremen, Germany, ${ }^{3}$ Now at Centre for Ocean and Atmospheric Sciences, \\ School of Environmental Sciences, University of East Anglia, Norwich, UK, ${ }^{4}$ Department of Geography, University College \\ London, London, UK, ${ }^{5}$ Now at School of Earth and Environmental Sciences, University of St Andrews, St Andrews, UK, \\ ${ }^{6}$ College of Earth, Ocean, and Atmospheric Sciences, Oregon State University, Corvallis, OR, USA, ${ }^{7}$ College of Marine Science, \\ University of South Florida, St. Petersburg, FL, USA
}

Abstract The late Miocene-early Pliocene was a time of global cooling and the development of modern meridional thermal gradients. Equatorial Pacific sea surface conditions potentially played an important role in this global climate transition, but their evolution is poorly understood. Here we present the first continuous late Miocene-early Pliocene (8.0-4.4 Ma) planktic foraminiferal stable isotope records from eastern equatorial Pacific Integrated Ocean Drilling Program Site U1338, with a new astrochronology spanning 8.0-3.5 Ma. $\mathrm{Mg} / \mathrm{Ca}$ analyses on surface dwelling foraminifera Trilobatus sacculifer from carefully selected samples suggest that mean sea surface temperatures (SSTs) are $\sim 27.8 \pm 1.1^{\circ} \mathrm{C}(1 \sigma)$ between 6.4 and $5.5 \mathrm{Ma}$. The planktic foraminiferal $\delta^{18} \mathrm{O}$ record implies a $2^{\circ} \mathrm{C}$ cooling between 7.2 and $6.1 \mathrm{Ma}$ and an up to $3^{\circ} \mathrm{C}$ warming between 6.1 and 4.4 Ma, consistent with observed tropical alkenone paleo-SSTs. Diverging fine-fraction-toforaminiferal $\delta^{13} \mathrm{C}$ gradients likely suggest increased upwelling between 7.1-6.0 and 5.8-4.6 Ma, concurrent with the globally recognized late Miocene Biogenic Bloom. This study shows that both warm and asymmetric mean states occurred in the equatorial Pacific during the late Miocene-early Pliocene. Between 8.0-6.5 and 5.2-4.4 Ma, low east-west $\delta^{18} \mathrm{O}$ and SST gradients and generally warm conditions prevailed. However, an asymmetric mean climate state developed between 6.5 and $5.7 \mathrm{Ma}$, with larger east-west $\delta^{18} \mathrm{O}$ and SST gradients and eastern equatorial Pacific cooling. The asymmetric mean state suggests stronger trade winds developed, driven by increased meridional thermal gradients associated with global cooling and declining atmospheric $p \mathrm{CO}_{2}$ concentrations. These oscillations in equatorial Pacific mean state are reinforced by Antarctic cryosphere expansion and related changes in oceanic gateways (e.g., Central American Seaway/Indonesian Throughflow restriction).

\section{Introduction}

The equatorial Pacific Ocean comprises $50 \%$ of all tropical water masses and plays an essential role in global heat transport, carbon cycling and hydrological cycling. Variations in sea surface temperatures (SSTs) affect local Hadley and Walker cells, thereby perturbing global atmospheric circulation patterns (Bryden \& Brady, 1985; Lyle et al., 2010; Takahashi et al., 1997). The modern equatorial Pacific Ocean is influenced by the El Niño-Southern Oscillation (ENSO), which causes widespread and global precipitation and temperature anomalies (Alexander et al., 2002; Goddard et al., 2001). ENSO oscillates interannually between a warm "El Niño" phase, with weak east-west equatorial SST gradients and a generally deep thermocline across the equatorial Pacific, and a cold "La Niña" phase, with an amplified east-west SST gradient and eastern equatorial Pacific thermocline shoaling and SST cooling (Alexander et al., 2002; Goddard et al., 2001; Trenberth, 1997).

The evolution of modern equatorial Pacific SSTs and upper ocean circulation is not fully understood. Paleoceanographical records indicate that modern patterns, including the appearance of the eastern equatorial cold tongue, developed during the late Miocene to early Pliocene (Figure 1) (Gasperi \& Kennett, 1993; Herbert et al., 2016; Kennett et al., 1985; Pisias et al., 1995; Rousselle et al., 2013; Savin et al., 1985). Permanent El Niño-like conditions, with generally warm equatorial SSTs and a minimal east-west thermal gradient are proposed for the Pliocene (Dekens et al., 2008; Ford et al., 2012; Groeneveld et al., 2006; Lawrence et al., 2006; Ravelo et al., 2014; Seki et al., 2012; Steph et al., 2006; Wara et al., 2005). However, late Miocene sea surface conditions are not well understood due to the current lack of high-resolution surface 
(a) Equatorial Pacific Sea Surface Circulation and Temperatures $\left({ }^{\circ} \mathrm{C}\right)$

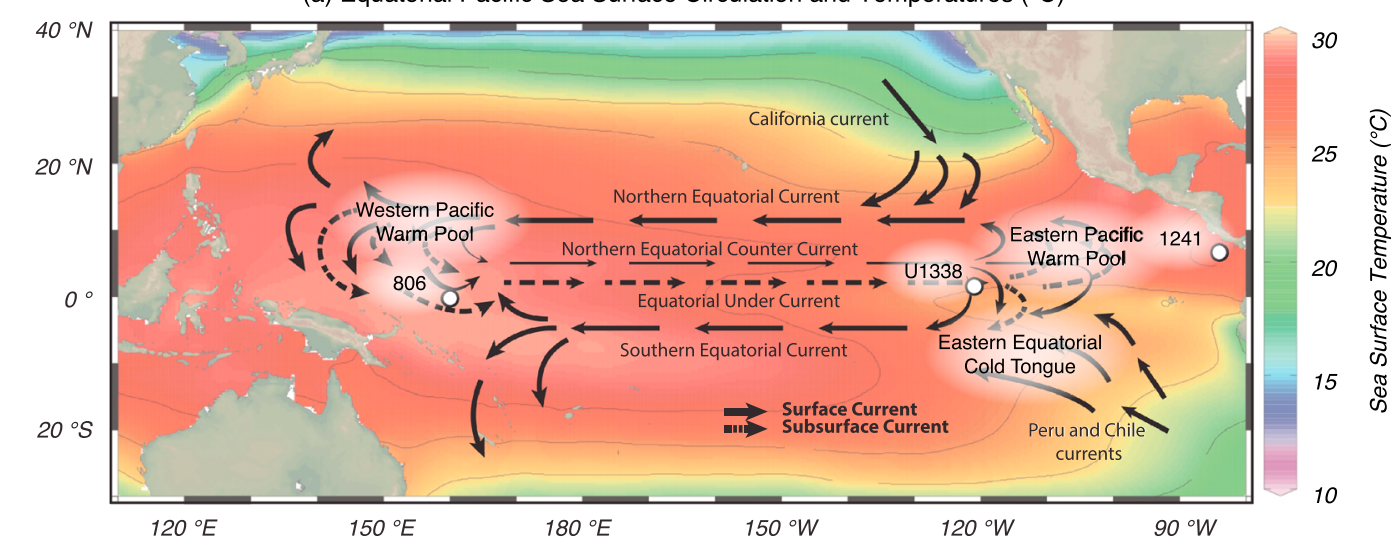

(b) Equatorial $\left(2^{\circ} \mathrm{N}\right)$ Pacific Temperature Transect $\left({ }^{\circ} \mathrm{C}\right)$

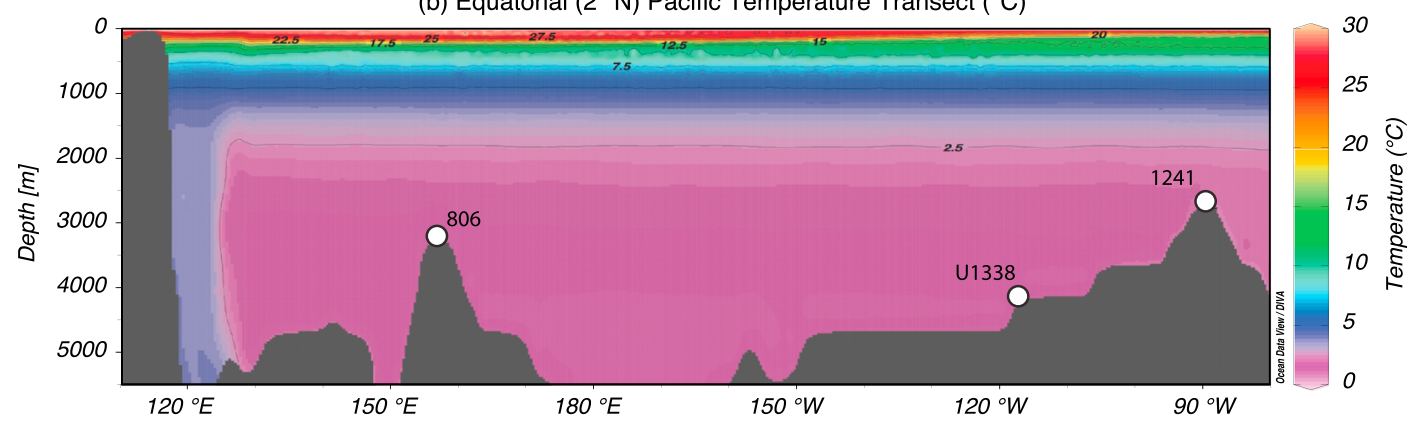

Figure 1. (a) Modern equatorial sea surface temperatures and upper ocean currents, with site locations indicated for ODP 806,1241 and IODP U1338. (b) Temperature transect at $2^{\circ} \mathrm{N}$ across the equatorial Pacific, with locations of 806,1241 , and U1338 (Locarnini et al., 2010; Pisias et al., 1995; Schlitzer, 2010).

ocean records from the equatorial Pacific Ocean, and in particular from the eastern equatorial Pacific region covering intervals prior to $6 \mathrm{Ma}$. Evidence exists for generally warm equatorial Pacific surface ocean conditions between $\sim 12$ and 5 Ma (Gasperi \& Kennett, 1993; LaRiviere et al., 2012). However, these observations contradict evidence for either oscillating dominant El Niño-/La Niña-like conditions during the late Miocene (Nathan \& Leckie, 2009) or stable E-W equatorial SST gradients for the last 12 Myr (Zhang et al., 2014). Further complicating understanding of the equatorial Pacific Ocean, is the globally recognized, but not globally synchronous Late Miocene Biogenic Bloom (LMBB), which occurred in both upwelling zones and oligotrophic regions between $\sim 8.0$ and $4.5 \mathrm{Ma}$, and may reflect increased surface ocean nutrient delivery via either increased upwelling of cool nutrient-rich waters or increased continental runoff (Diester-Haass et al., 2002, 2005, 2006; Grant \& Dickens, 2002; Hermoyian \& Owen, 2001; Liao \& Lyle, 2014; Lyle \& Baldauf, 2015; Herbert et al., 2016). However, a forcing mechanism of increased upwelling (Grant \& Dickens, 2002) is difficult to reconcile with observations of eastern equatorial Pacific surface warmth and a deep E-W thermocline across the equatorial Pacific Ocean (LaRiviere et al., 2012).

Here we investigate the evolution of eastern equatorial Pacific surface ocean conditions during the late Miocene to early Pliocene (8.0 to $4.4 \mathrm{Ma}$ ) using samples from Integrated Ocean Drilling Program (IODP) Site U1338. We selected Site U1338 because it has expanded late Miocene-early Pliocene sedimentary sequences and is ideal for resolving the poorly understood interval prior to 6.0 Ma. Recently discovered stratigraphic issues affect the original late Miocene-early Pliocene chronology (Drury et al., 2016, 2018). We therefore generated a new astrochronology for the 8.0 to $3.5 \mathrm{Ma}$ interval at Site U1338 using published benthic Cibicidoides mundulus $\delta^{18} \mathrm{O}$ records (Drury et al., 2016). We analyzed planktic foraminiferal Trilobatus sacculifer ( $T$. sacculifer) $\mathrm{Mg} / \mathrm{Ca}$ ratios to broadly evaluate average SSTs at Site U1338 and enable a comparison to alkenone $\left(U_{37}^{k^{\prime}}\right)$ and clumped isotopes $\left(\Delta_{47}\right)$ SST estimates from the same location (Drury \& John, 2016; Rousselle et al., 2013). We generated the first continuous T. sacculifer $\delta^{18}$ O record spanning the late Miocene to early Pliocene and combined these records with published $U_{37}^{k^{\prime}}$ and benthic $\delta^{18} \mathrm{O}$ records (Drury et al., 2016; Rousselle et al., 2013) to reconstruct the SST evolution in the eastern equatorial Pacific 
between 8.0 and 4.4 Ma. We then assessed eastern equatorial Pacific Ocean productivity and upwelling by comparing planktic and benthic foraminiferal, and fine fraction $(<63 \mu \mathrm{m}) \delta^{13} \mathrm{C}$ records (Drury et al., 2016; Reghellin et al., 2015). Finally, we combined multiple proxy records from Site U1338 and ODP Sites 806 (western equatorial Pacific) and 1241 (far eastern equatorial Pacific) to establish east-west equatorial planktic foraminiferal $\delta^{18} \mathrm{O}$ and SST gradients, determine the equatorial Pacific Ocean mean state, and reconcile apparent contradictions between a dominant late Miocene El Niño-like state, and high, upwelling-driven productivity during the LMBB. Finally, we investigate the relationship between the mean state of the equatorial Pacific Ocean and the evolution of oceanic gateways and global climate.

\section{Materials and Methods}

\subsection{Equatorial Pacific Ocean Paleoceanographic Setting (IODP Site U1338)}

Modern equatorial Pacific Ocean surface circulation (Figure 1a) reflects tropical atmospheric circulation patterns and the change in the direction of the Coriolis force across the equator (Pisias et al., 1995). The late Miocene to early Pliocene equatorial Pacific Ocean surface circulation broadly resembled modern circulation (Gasperi \& Kennett, 1993; Kennett et al., 1985; Pisias et al., 1995; Savin et al., 1985), with sedimentological evidence for high biogenic deposition in the equatorial Pacific Ocean indicating that equatorial divergence existed since the late Eocene (Mitchell et al., 2003; Moore et al., 2004; Van Andel et al., 1975). The Intertropical Convergence Zone is situated north of the equator, between the Northern and Southern Equatorial currents (NEC, SEC), which drive warm waters westward to form the Western Pacific Warm Pool (WPWP). The warm water build-up in the WPWP drives the warm North Equatorial Counter Current (NECC) and the cooler Equatorial Undercurrent (EUC) eastward. The NECC feeds the Eastern Pacific Warm Pool (EPWP) and the EUC combines with the cool Peru and Chile currents to form the Eastern Equatorial Cold Tongue (EECT). Thus, the regional physical oceanography results in an asymmetrical thermocline, which is deepest in the western equatorial Pacific Ocean (Figure 1b).

Much of the late Neogene work in the eastern equatorial Pacific has focused on the last $6 \mathrm{Ma}$ (Dekens et al., 2008; Ford et al., 2012; Groeneveld et al., 2006; Lawrence et al., 2006; Steph et al., 2006; Wara et al., 2005); however, records covering the interval prior to $6 \mathrm{Ma}$ are distinctly fewer and low-resolution (Rousselle et al., 2013; Seki et al., 2012). We selected Site U1338 $\left(2^{\circ} 30.469^{\prime} \mathrm{N}, 117^{\circ} 58.178^{\prime} \mathrm{W}\right.$; water depth $4200 \mathrm{~m}$, paleowater depth 3850-4050 m), which was located in the center of the equatorial Pacific productivity belt during the late Miocene-early Pliocene (Expedition 320/321 Scientists, 2010; Lyle \& Baldauf, 2015; Pälike et al., 2010) (Figures 1a and 1b). An expanded composite sedimentary section of calcareous nannofossil ooze with siliceous microfossil-rich intervals was recovered during IODP Expedition 321 (Expedition 320/321 Scientists, 2010; Wilkens et al., 2013). Planktic foraminifera comprise $>80 \%$ of the $>63 \mu \mathrm{m}$ fraction, with variable fair to poor preservation (Drury et al., 2014; Hayashi et al., 2013).

\subsection{Planktic Foraminiferal Stable Isotope Analyses}

We analyzed 212 samples every $\sim 50 \mathrm{~cm}$ (average temporal resolution: $16 \mathrm{kyr}$ ) along the revised composite splice between 62 and $185 \mathrm{~m}$ core composite depth below sea floor (CCSF-A; Wilkens et al., 2013). Each $15 \mathrm{~cm}^{3}$ sample was freeze dried, wet sieved at $63 \mu \mathrm{m}$, and oven dried at $45^{\circ} \mathrm{C}$. We analyzed two to eight mixed layer planktic foraminifera $T$. sacculifer tests $(250-355 \mu \mathrm{m}$; previously Globogerinoides sacculifer; Spezzaferri et al., 2015) for $\delta^{18} \mathrm{O}$ and $\delta^{13} \mathrm{C}$ (supporting information Table S1). We preferentially selected translucent tests, whereas we avoided fragmented tests and tests with visible inorganic calcite overgrowth and/or dissolution. Prior to analysis, tests were ultrasonicated in methanol to remove any fine-grained particles. Samples were analyzed using a Thermo Kiel IV-Finnigan Mat $253\left(70^{\circ} \mathrm{C} 105 \% \mathrm{H}_{3} \mathrm{PO}_{4}\right)$ in the Qatar Stable Isotope Laboratory at Imperial College London. During the project, analytical precision was $0.07 \%$ o for $\delta^{18} \mathrm{O}$ and $0.04 \%$ or $\delta^{13} \mathrm{C}$. Replicates of $10 \%$ of the data reveal that reproducibility and natural sample variability are better than $0.1 \%$ for both $\delta^{18} \mathrm{O}$ and $\delta^{13} \mathrm{C}$. Results are reported against Vienna Peedee Belemnite (VPDB) using the standard $\delta$ notation expressed in per mill (\%o).

\subsection{Planktic Foraminiferal Trace Element Analyses}

Between 90 and 120 m CCSF-A, 12 samples that contained sufficiently abundant and well-preserved T. sacculifer were selected for trace element/Ca analysis (supporting information Table S2). T. sacculifer tests were selected from multiple size fractions $(250-355 \mu \mathrm{m}=\sim 18$ tests; 355-425 $\mu \mathrm{m}=\sim 10$ tests; $425-500 \mu \mathrm{m}=\sim 6$ tests) to determine if test size influenced $\mathrm{Mg} / \mathrm{Ca}$, as previously reported (Elderfield et al., 2002). Samples 
were cleaned using the adapted $\mathrm{Cd}$-cleaning protocol, including the reductive and oxidative steps, but excluding the corrosive DTAP step (Boyle \& Keigwin, 1985; Martin \& Lea, 2002). Planktic foraminiferal $\mathrm{Mg} / \mathrm{Ca}, \mathrm{Sr} / \mathrm{Ca}, \mathrm{Fe} / \mathrm{Ca}, \mathrm{Al} / \mathrm{Ca}$, and $\mathrm{Mn} / \mathrm{Ca}$ ratios were measured on the Varian ICP-OES at University College London, using the intensity ratio calibration method (de Villiers et al., 2002). Fe/Ca, Al/Ca, and Mn/Ca ratios were used to monitor cleaning efficacy (Barker et al., 2003; Boyle \& Keigwin, 1985; Elderfield et al., 2010). During this project, analytical precision was $0.025 \mathrm{mmol} / \mathrm{mol}(2 \sigma)$ for $\mathrm{Mg} / \mathrm{Ca}$ and $0.007 \mathrm{mmol} / \mathrm{mol}(2 \sigma)$ for $\mathrm{Sr} / \mathrm{Ca}$. Repeated analysis of an limestone standard (ECRM 752-1) yielded a value of $3.72 \pm 0.03 \mathrm{mmol} / \mathrm{mol}$, in excellent agreement with Greaves et al. (2005). Replicates of $14 \%$ of the samples indicate a reproducibility $(2 \sigma)$ of $0.18 \mathrm{mmol} / \mathrm{mol}\left(0.73^{\circ} \mathrm{C}\right)$ for $\mathrm{Mg} / \mathrm{Ca}$ and $0.01 \mathrm{mmol} / \mathrm{mol}$ for $\mathrm{Sr} / \mathrm{Ca}$. $\mathrm{Mg} / \mathrm{Ca}$ ratios from the larger test sizes were divided by a size fraction correction factor, calculated by normalizing $\mathrm{Mg} / \mathrm{Ca}$ ratios to the smallest size fraction and using a linear regression through the normalized data (see supporting information). The sizespecific correction introduces additional uncertainty of $0.16 \mathrm{mmol} / \mathrm{mol}$, increasing the overall $\mathrm{Mg} / \mathrm{Ca}$ uncertainty to $0.24 \mathrm{mmol} / \mathrm{mol}\left(0.97^{\circ} \mathrm{C}\right)$ for size-corrected samples.

To correct for potential effects of dissolution on $\mathrm{Mg} / \mathrm{Ca}$ ratios due to decreasing $\left[\mathrm{CO}_{3}{ }^{2-}\right]$ with increasing water depth (Dekens et al., 2002; Elderfield et al., 2006; Rosenthal et al., 2006; Yu \& Elderfield, 2008), the paleowater depth was calculated for each sample based on the U1338 paleowater depth reconstructions in Pälike et al. (2012) (supporting information Table S2). We infer that the late Miocene-early Pliocene $\left[\mathrm{CO}_{3}{ }^{2-}\right]$ was similar to the present day, as the Pacific Ocean calcite compensation depth (CCD) reconstructions indicate that the CCD was only $100 \mathrm{~m}$ shallower than today (Pälike et al., 2012). Thus, we converted the planktic Mg/Ca ratios to SSTs using the T. sacculifer calibration of Dekens et al. (2002), which incorporates a Pacific Ocean-specific correction factor for dissolution due to decreasing $\left[\mathrm{CO}_{3}{ }^{2-}\right]$ with increasing water depth. We additionally corrected for past seawater $\mathrm{Mg} / \mathrm{Ca}$ changes, using the approach of Lear et al. (2000):

$$
\mathrm{Mg} / \mathrm{Ca}=0.37\left(\frac{\mathrm{Mg} / \mathrm{Ca}_{\text {MioPliosw }}}{\mathrm{Mg} / \mathrm{Ca}_{\text {Modsw }}}\right) e^{0.09[T-0.36(\text { depth })-2.0]}
$$

$\mathrm{Mg} / \mathrm{Ca}$ is the $T$. sacculifer calcite $\mathrm{Mg} / \mathrm{Ca}$ ratio, $T$ is calculated SSTs $\left({ }^{\circ} \mathrm{C}\right)$ and depth $(\mathrm{m})$ is the palaeowater depth taken from Pälike et al. (2012). Modern seawater $\mathrm{Mg} / \mathrm{Ca}\left(\mathrm{Mg} / \mathrm{Ca} \mathrm{Modsw}_{\text {) }}\right.$ is $5.2 \mathrm{~mol} / \mathrm{mol}$ (Ries, 2004) and we use an average Miocene-Pliocene $\mathrm{Mg} / \mathrm{Ca}$ seawater value $\left(\mathrm{Mg} / \mathrm{Ca}_{\text {MioPliosw) }}\right.$ of $4.1 \pm 0.05 \mathrm{~mol} / \mathrm{mol}$ (Higgins \& Schrag, 2015). Over the $\mathrm{Mg} / \mathrm{Ca}_{\text {seawater }}$ range considered for the studied interval $(4.05-4.15 \mathrm{~mol} / \mathrm{mol}$ ), any nonlinear effects of $\mathrm{Mg} / \mathrm{Ca}_{\text {seawater }}$ on reconstructed SSTs are likely minor compared to the linear correction applied in equation (1) (Evans, Brierley, et al., 2016). The past seawater $\mathrm{Mg} / \mathrm{Ca}$ correction introduces an additional uncertainty of $0.25^{\circ} \mathrm{C}$, increasing the total temperature uncertainty to $0.98^{\circ} \mathrm{C}$ for nonsize-corrected samples and $1.22^{\circ} \mathrm{C}$ for size-corrected samples. While seawater carbonate chemistry can influence $\mathrm{Mg} / \mathrm{Ca}$ in other species of planktic foraminifera (e.g., Evans, Wade, et al., 2016; Gray et al., 2018), culture studies indicate that T. sacculifer $\mathrm{Mg} / \mathrm{Ca}$ is insensitive to changes in seawater carbonate chemistry ( $<1 \% / 0.1 \mathrm{pH}$ units) (Allen et al., 2016); thus, no correction was made. Salinity may also influence T. sacculifer Mg/Ca (Hönisch et al., 2013). However, there is little constraint on Miocene-Pliocene equatorial Pacific Ocean seawater salinity and a \pm 1 PSU change in salinity would only result in a temperature change of $\sim \pm 0.5^{\circ} \mathrm{C}$, which is within the temperature calibration error (Hönisch et al., 2013). Recent research found that the Globigerinoides ruber Mg/Ca temperature sensitivity was $6 \% /{ }^{\circ} \mathrm{C}$, substantially lower than the widely applied $9 \% /{ }^{\circ} \mathrm{C}$ temperature sensitivity (Gray et al., 2018). If future calibration work also demonstrates similar results for $T$. sacculifer, $T$. sacculifer-derived $\mathrm{Mg} / \mathrm{Ca}$ SSTs would need reexamining.

\section{Astrochronology}

The age model for Site U1338 was originally published in Drury et al. (2016), by stratigraphically correlating Site U1338 to the astronomically tuned North Atlantic ODP Site 982 (Hodell et al., 2001). However, recent studies show major issues with the Site 982 shipboard composite splice, with considerable consequences for the Hodell et al. (2001) astrochronology (Bickert et al., 2004; Drury et al., 2018; Khelifi et al., 2012; van der Laan et al., 2005). As a result, it became crucial to develop a new, independent astrochronology for Site U1338. Since the publication of Drury et al. (2016), a highly-accurate astrochronology was developed for the 8.3 to 6.0 Ma interval at nearby IODP Site U1337, by correlating the benthic $\delta^{18} \mathrm{O}$ series to an equally weighted Laskar et al. (2004) eccentricity, tilt, and Northern Hemisphere precession tuning target without a phase shift (E+T-P) (Drury et al., 2017). 


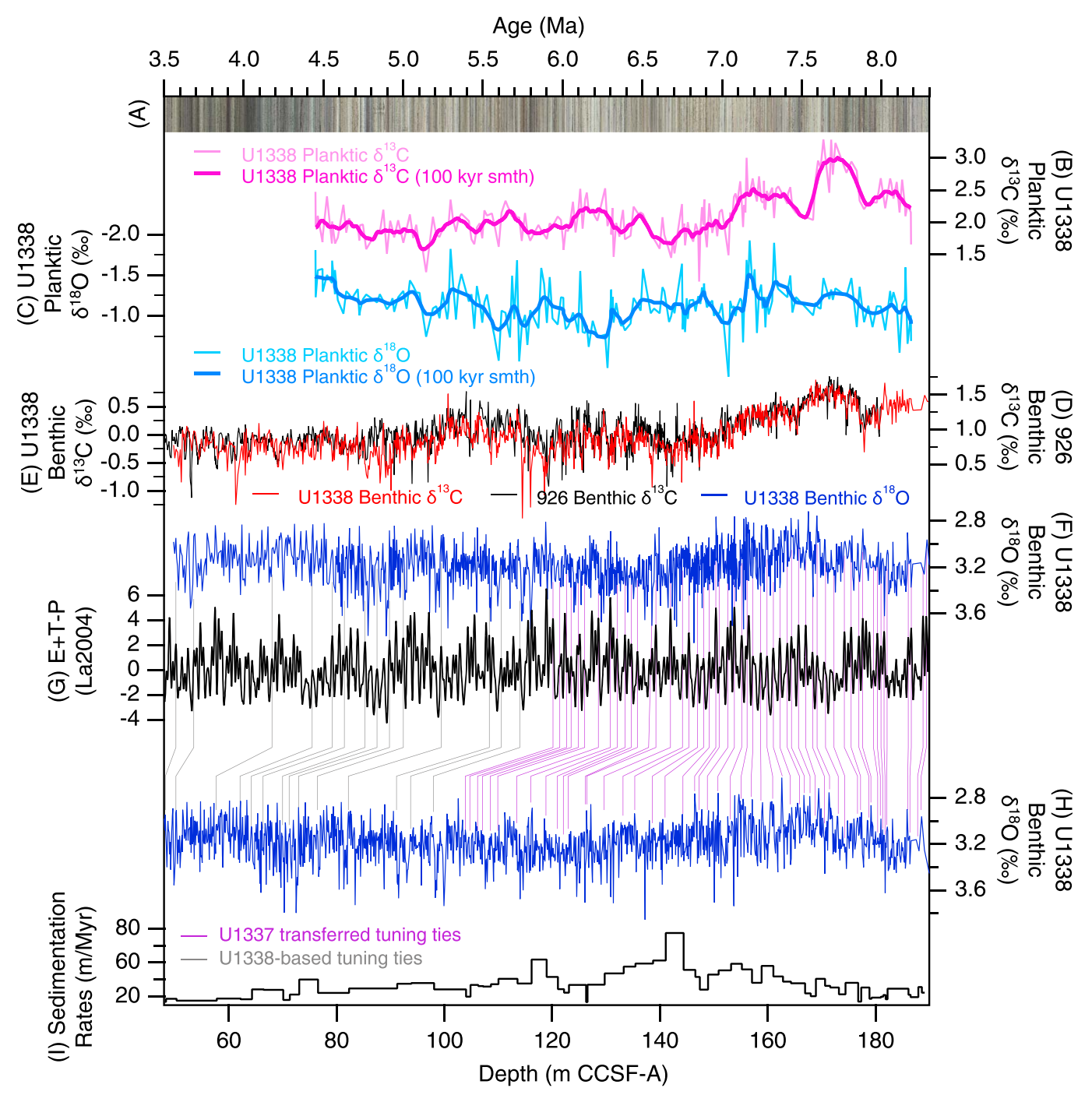

Figure 2. (a) Spliced Site U1338 core photo (Wilkens et al., 2013, 2017) and planktic T. sacculifer (b) $\delta^{13} \mathrm{C}$ and (c) $\delta^{18} \mathrm{O}$ stable isotope records from Site U1338 (this study). Benthic foraminiferal (d) $\delta^{13} \mathrm{C}$ from ODP Site 926 on its independent astrochronology (Drury et al., 2017; Zeeden et al., 2013; Wilkens et al., 2017) and (e) $\delta^{13} \mathrm{C}$ and (f) $\delta^{18} \mathrm{O}$ stratigraphies from IODP Site U1338 on the new astrochronology presented here. (g) The E+T-P tuning target (Laskar et al., 2004) used to generate the new Site U1338 astrochronology. (h) Benthic C. mundulus $\delta^{18} \mathrm{O}$ stratigraphy from Site U1338 on composite depth (Drury et al., 2016; Wilkens et al., 2013). (i) New sedimentation rates for Site U1338 based on the new astrochronology. The tuning ties are distinguished between ties transferred from the high-resolution astrochronology developed at Site U1337 in dark gray (Drury et al., 2017) and those based solely at Site U1338 in dark purple.

Considering the similarities between the Sites U1337 and U1338 isotope stratigraphies, we used the same E+T-P tuning target to generate the Site U1338 astrochronology. Milankovitch-scale cyclicity observed in high-resolution XRF core-scanning data, composite core images, and high-resolution stable isotope data from Sites U1337 and U1338 (Drury et al., 2016, 2017; Lyle et al., 2012; Shackford et al., 2014; Wilkens et al., 2013) enable a highly accurate depth-depth correlation between the neighboring sites using the Site-2Site functions included in CODD (Code for Ocean Drilling Data) (Wilkens et al., 2017) (supporting information Table S3). Using the U1337-U1338 correlation, we transferred the Site U1337 astrochronology to the Site U1338 depth scale, resulting in a high-resolution astrochronology for the 8.0 to $6.0 \mathrm{Ma}$ interval (53 light green ties, Figure 2; supporting information Table S4 and Figure S6). Once ties were transferred to Site U1338, the alignment between the Site U1338 benthic $\delta^{18} \mathrm{O}$ minima and the E+T-P maxima was visually assessed to inspect whether each tie was optimally placed. We then extended the astrochronology at U1338 to span 

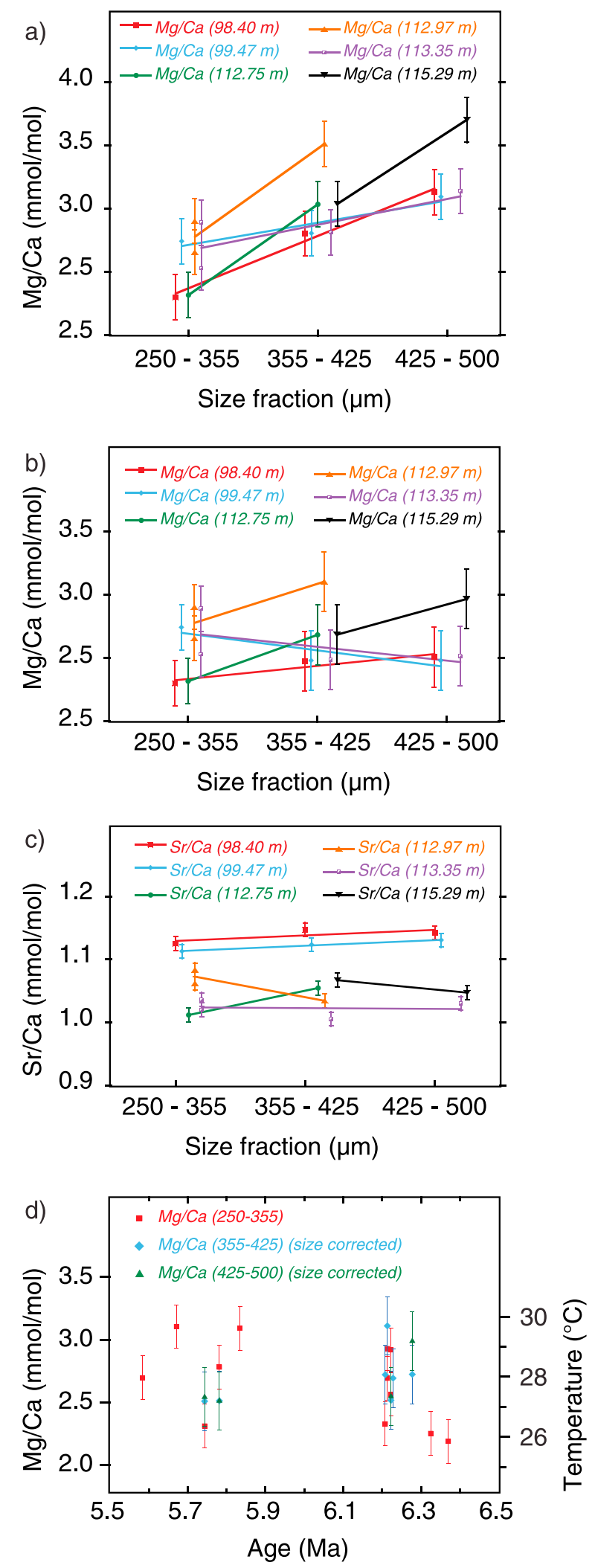

Figure 3. Planktic T. sacculifer (a) uncorrected Mg/Ca ratios, (b) size-corrected Mg/Ca ratios, (c) $\mathrm{Sr} / \mathrm{Ca}$ ratios, and (d) size- and seawater-corrected $\mathrm{Mg} / \mathrm{Ca}$ ratios, $\mathrm{Mg} / \mathrm{Ca}$-derived SSTs plotted versus age. Figures 3a-3c show only data from samples where multiple size fractions were measured. Figure $3 \mathrm{~d}$ shows all data. 
the entire 8.0 to $3.5 \mathrm{Ma}$ interval, by generating 14 additional ties between $\delta^{18} \mathrm{O}$ minima and E+T-P maxima from 6.0 to 3.5 Ma (dark green ties, Figure 2; supporting information Table S4 and Figure S6). The 8.0-3.5 Ma Site U1338 astrochronology is supported by the agreement in the amplitude modulations of the obliquity component of the $\mathrm{U} 1338 \delta^{18} \mathrm{O}$ record and of obliquity from La2004 (determined using the TimeOpt methodology for the R-package astrochron; see supporting information) (Meyers, 2014, 2015; Zeeden et al., 2015). Our new astrochronology is further supported by the close agreement of the Site U1338 benthic $\delta^{13} \mathrm{C}$ record and the equatorial Atlantic ODP Site 926 benthic $\delta^{13} \mathrm{C}$ record, which has a highresolution astrochronology generated independently of the stable isotope stratigraphy (Figures $2 \mathrm{~d}$ and $2 \mathrm{e}$; Drury et al., 2017; Wilkens et al., 2017; Zeeden et al., 2013).

\section{Results}

\subsection{Site U1338 T. sacculifer $\delta^{18} \mathrm{O}$ and $\delta^{13} \mathrm{C}$}

The Site U1338 T. sacculifer $\delta^{18} \mathrm{O}$ data decrease by $\sim 0.5 \%$ o between 8.0 and $4.4 \mathrm{Ma}$, from average $\delta^{18} \mathrm{O}$ values of $-1.0 \%$ around $8.0 \mathrm{Ma}$ to $-1.5 \%$ o by $4.4 \mathrm{Ma}$ (Figure $2 \mathrm{c}$ ). Between $\sim 8.0$ and $7.2 \mathrm{Ma}$, average planktic $\delta^{18} \mathrm{O}$ decreases by $-0.5 \%$ o ( -1.0 to $-1.5 \%$ ), followed by a $0.65 \%$ increase $(-1.4$ to $-0.75 \%$ ) between 7.2 and 6.2 Ma. Between 6.2 and 4.4 Ma, average T. sacculifer $\delta^{18} \mathrm{O}$ decreases by $-0.75 \%$ o $(-0.75$ to $-1.5 \%$ ). The T. sacculifer $\delta^{13} \mathrm{C}$ data exhibit long-term (100 kyr smoothed) variability throughout the record (Figure 2b). Between 7.6 and 6.7 Ma, there is a long-term -1.2\%o shift from $\sim 2.9$ to $1.7 \%$ o. From 6.7 to $4.4 \mathrm{Ma}$, average $\delta^{13} \mathrm{C}$ is characterized by $0.2 \%$ o fluctuations around a $2.0 \%$ mean. Short-term ( $<100 \mathrm{kyr}$ ) variability is $\sim 0.6-$ $0.9 \%$ o for $T$. sacculifer $\delta^{18} \mathrm{O}$ and $\sim 0.5-0.7 \%$ o for T. sacculifer $\delta^{13} \mathrm{C}$.

\subsection{Site U1338 T. sacculifer Mg/Ca and Sr/Ca and Mg-Derived SSTs}

The $T$. sacculifer $\mathrm{Mg} / \mathrm{Ca}$ ratios increase with increasing test size in all samples where multiple size fractions were analyzed (Figure 3a). After a size fraction correction, the $\mathrm{Mg} / \mathrm{Ca}$ ratios in the $355-425$ and $425-$ $500 \mu \mathrm{m}$ fractions decline by $0.35 \pm 0.03\left(1.4 \pm 0.1^{\circ} \mathrm{C}\right)$ and $0.65 \pm 0.06\left(2.5 \pm 0.3^{\circ} \mathrm{C}\right) \mathrm{mmol} / \mathrm{mol}$, respectively; corrected $\mathrm{Mg} / \mathrm{Ca}$ ratios are similar between fractions within sample uncertainty (Figure $3 \mathrm{~b}$ ). The uncorrected $\mathrm{Sr} / \mathrm{Ca}$ ratios reveal no trend with increasing test size (Figure $3 \mathrm{c}$ ).

Size-corrected $\mathrm{Mg} / \mathrm{Ca}$ ratios range between 2.20 and $3.10 \mathrm{mmol} / \mathrm{mol}$, translating to a $26-30^{\circ} \mathrm{C}$ when accounting for late Miocene-early Pliocene $\mathrm{Mg} / \mathrm{Ca}_{\text {seawater }}$ (Figure $3 \mathrm{~d}$ ). Without a correction for past $\mathrm{Mg} / \mathrm{Ca}_{\text {seawater }}$ changes, Mg/Ca-derived SSTs would be $\sim 3^{\circ} \mathrm{C}$ lower $\left(23-27^{\circ} \mathrm{C}\right)$. In the remainder of this paper, $\mathrm{Mg} / \mathrm{Ca}$-derived SSTs corrected for past $\mathrm{Mg} / \mathrm{Ca}_{\text {seawater }}$ are reported. Across the entire interval, average $\mathrm{Mg} / \mathrm{Ca}$-derived SSTs are $27.8 \pm 1.1^{\circ} \mathrm{C}$. The coolest temperatures $\left(<26^{\circ} \mathrm{C}\right)$ are seen between $\sim 6.5$ and $6.2 \mathrm{Ma}$; by $5.8 \mathrm{Ma}$ temperatures increased and remained around $27-30^{\circ} \mathrm{C}$ between 5.8 and $5.5 \mathrm{Ma}$.

\section{Discussion}

\subsection{Eastern Equatorial Pacific Ocean Surface Conditions}

\subsubsection{Sea Surface Temperatures}

Late Miocene Mg/Ca-derived SSTs from Site U1338 average $27.8 \pm 1.1^{\circ} \mathrm{C}$ (Figure 3d). These Mg/Ca-derived SSTs, which are the first late Miocene trace element SST estimates for this region, agree with average Site U1338 alkenone $\mathrm{U}_{37^{-}}^{\mathrm{k}^{\prime}}$ and clumped isotope $\Delta_{47^{-}}$-derived SSTs of $\sim 27 \pm 1.2^{\circ} \mathrm{C}$ and $27 \pm 2{ }^{\circ} \mathrm{C}$, respectively (Drury \& John, 2016; Rousselle et al., 2013). The planktic Mg/Ca-derived SSTs support the accuracy of the $U_{37}^{k^{\prime}}$ temperatures, which are at the upper temperature limit of the $U_{37}^{k^{\prime}}$ calibration in this region (Herbert, 2003; Herbert et al., 2016; Rousselle et al., 2013). The Site U1338 SST estimates are about $3^{\circ} \mathrm{C}$ warmer than the modern SSTs $\left(24.7^{\circ} \mathrm{C}\right.$; Locarnini et al., 2013) observed at the paleoposition of Site U1338 at 6 Ma (Pälike et al., 2012). The combined Site U1338 SSTs further corroborate the generally warm regional eastern equatorial alkenone and $\mathrm{Mg} / \mathrm{Ca}$ SSTs $\left(26-28^{\circ} \mathrm{C}\right.$ at ODP Sites 846,847 and 1241) across the MiocenePliocene boundary and into the early Pliocene (Dekens et al., 2007; Groeneveld et al., 2006; Lawrence et al., 2006; Seki et al., 2012; Wara et al., 2005).

Here we use Site U1338 $U_{37}^{k^{\prime}}$-derived SSTs, and planktic and benthic $\delta^{18} \mathrm{O}$ to assess the contributions of temperature, global ice volume, and salinity to the planktic $\delta^{18} \mathrm{O}$ records (Figure 4). Planktic $\delta^{18} \mathrm{O}$ reflects the temperature and the surrounding seawater $\delta^{18} \mathrm{O}\left(\delta^{18} \mathrm{O}_{\mathrm{sw}}\right)$ and can be used to estimate SSTs $\left(\sim-0.23 \%{ }^{\circ}{ }^{\circ} \mathrm{C}\right.$; Epstein et al., 1953; Bemis et al., 1998) when local $\delta^{18} \mathrm{O}_{\mathrm{sw}}$ variations (e.g., changes in 


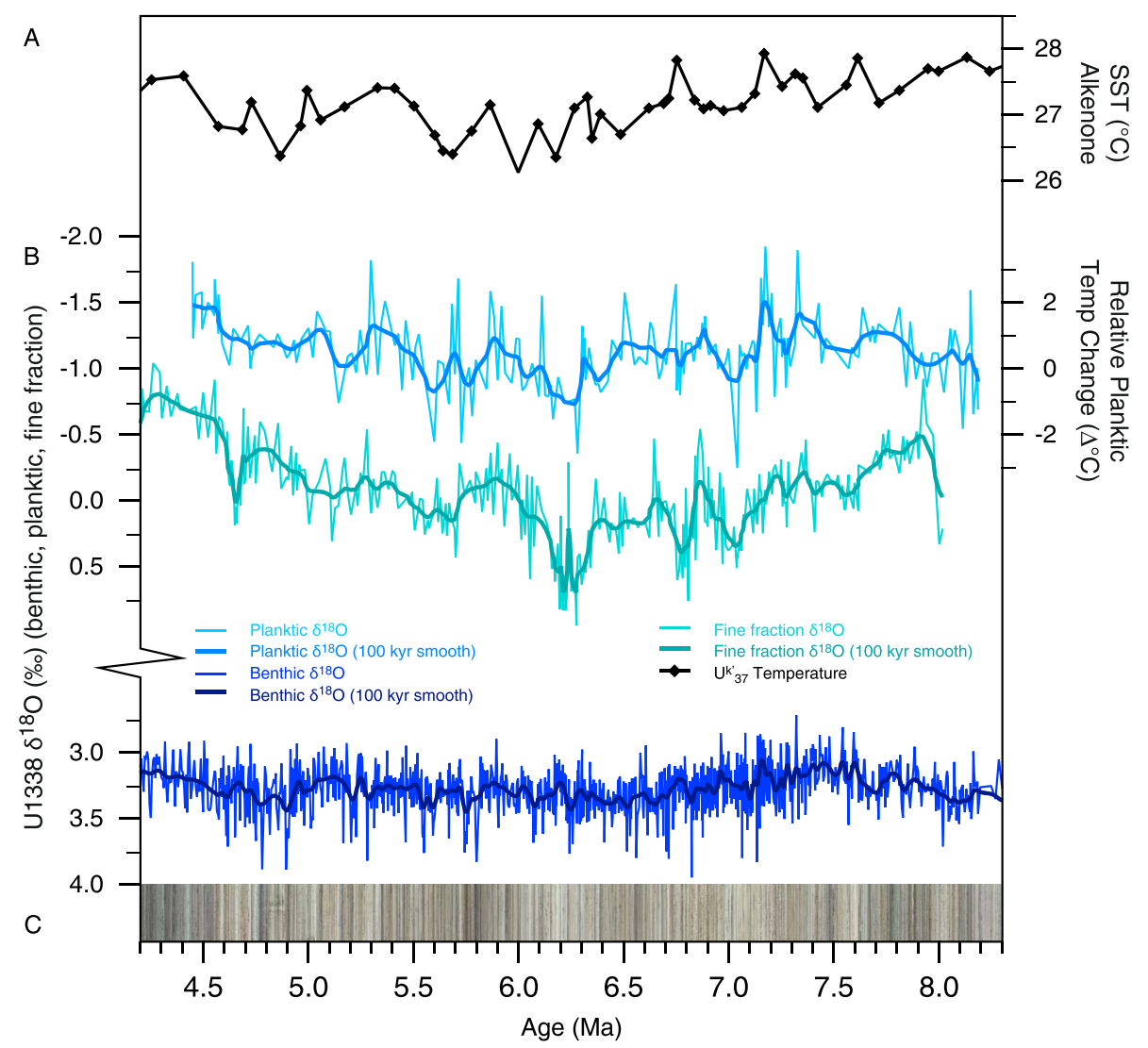

Figure 4. Overview of the Site U1338 (a) $U_{37}^{k^{\prime}}$-derived SSTs (Rousselle et al., 2013), (b) $\delta^{18} \mathrm{O}$ records on the same axis from planktic (this study) and benthic foraminifera (Drury et al., 2016), as well as from the fine fraction $(<63 \mu \mathrm{m})$ (Reghellin et al., 2015), and (c) the spliced Site U1338 core photo (Wilkens et al., 2013, 2017). The relative temperature change approximation derived on the planktic $\delta{ }^{18} \mathrm{O}$ using the relationship $\sim-0.23 \%$ o $/{ }^{\circ} \mathrm{C}$ (Epstein et al., 1953) is shown on the right axis in Figure $4 \mathrm{~b}$.

global ice volume, salinity (0.5\%/psu) and pH), diagenesis and vital effects are known (Edgar et al., 2015, 2017; Katz et al., 2010; Rohling \& Bigg, 1998; Shackleton \& Opdyke, 1973; Spero et al., 1997; Spero \& Lea, 1993; Spero \& Williams, 1988). To circumvent unknown changes in past $\delta^{18} \mathrm{O}_{s w}$, we use the relationship of $\sim-0.23 \% /{ }^{\circ} \mathrm{C}$ (slope of foraminiferal $\delta^{18} \mathrm{O}-\mathrm{T}$ relationship derived by Epstein et al., 1953), to provide a first-order approximation of relative temperature change based on the planktic $\delta^{18} \mathrm{O}$ record (Figure $4 \mathrm{~b}$, right axis). Selecting visually well-preserved $T$. sacculifer minimized the effect of diagenesis on the planktic $\delta^{18} \mathrm{O}$ record, supported by scanning electron microscopy on T. sacculifer from Site U1338 showing that inorganic calcite overgrowths and infilling are absent, and that original growth features are retained (Drury et al., 2014). Although palaeo-vital effects remain difficult to constrain (Birch et al., 2013; Nathan \& Leckie, 2009), by selecting $T$. sacculifer from a narrow and consistent size fraction at Site U1338, vital effects relating to ontogenic changes likely remained comparable throughout the record.

As expected, the $\mathrm{U} 1338$ planktic $\delta^{18} \mathrm{O}$ record shows greater variability than the benthic $\delta^{18} \mathrm{O}$ record, suggesting the temporal planktic $\delta^{18} \mathrm{O}$ trends are primary (e.g., reflecting surface ocean variability) and not the result of diagenetic overprinting. Between 7.2 and $6.1 \mathrm{Ma}$, planktic $\delta^{18} \mathrm{O}$ increases by $\sim 0.5 \%$, which equates to a $\sim 2^{\circ} \mathrm{C}$ cooling if driven by SSTs alone (Figure $4 \mathrm{~b}$ ). It seems reasonable to discuss the planktic $\delta^{18} \mathrm{O}$ record in terms of SST changes between 7.2 and $6.1 \mathrm{Ma}$, as the $\sim 2^{\circ} \mathrm{C}$ cooling is similar to the observed $\mathrm{U}_{37}^{\mathrm{k}^{\prime}}$ SST cooling (Figures $4 \mathrm{a}$ and $4 \mathrm{~b}$ ) and the global late Miocene cooling trend ( 7.5-6 Ma) (Herbert et al., 2016). Between 6.2 and $4.4 \mathrm{Ma}$, planktic $\delta^{18} \mathrm{O}$ decreases by $\sim 0.8 \%$ (Figure $4 \mathrm{~b}$ ), suggesting a $3^{\circ} \mathrm{C}$ warming, if this change is solely associated with temperature, whilst the $\mathrm{U}_{37}^{\mathrm{k}^{\prime}}$-derived SSTs only warm by $\sim 2^{\circ} \mathrm{C}$ (Figures $4 \mathrm{a}$ and $4 \mathrm{~b}$ ). Despite the $\sim 1^{\circ} \mathrm{C} \delta^{18} \mathrm{O}-\mathrm{U}_{37}^{k^{\prime}}$ offset, the $\delta^{18} \mathrm{O}$-derived $3^{\circ} \mathrm{C}$ warming agrees well with the timing and 
magnitude of the global warming trend marking the end of the late Miocene cooling (Herbert et al., 2016). It is therefore reasonable to discuss the planktic $\delta^{18} \mathrm{O}$ changes between 6.2 and $4.4 \mathrm{Ma}$ as mostly related to temperature change. The $1^{\circ} \mathrm{C}$ offset between $\delta^{18} \mathrm{O}$ - and $\mathrm{U}_{37}^{\mathrm{k}^{\prime}}$-derived SSTs most likely reflects a decrease in global ice volume additionally influencing planktic $\delta^{18} \mathrm{O}$. A decline in Antarctic ice volume is supported by a reduction in average benthic $\delta^{18} \mathrm{O}$ from 4.7 to $4.4 \mathrm{Ma}$ and early Pliocene ice-proximal continental shelf and slope records of ice retreat from West and East Antarctica (Cook et al., 2013; Drury et al., 2016; Gulick et al., 2017; McKay et al., 2009).

5.1.2. Water Column $\delta^{13} \mathrm{C}$ Structure: Implications for Paleoproductivity

We reconstructed vertical water mass structure and biogenic bloom extent by integrating the new Site U1338 planktic $\delta^{13} \mathrm{C}$ data with fine fraction $\left(<63 \mu \mathrm{m}\right.$ ) (Reghellin et al., 2015) and benthic $\delta^{13} \mathrm{C}$ records (Drury et al., 2016). At Site U1338, the $<63 \mu \mathrm{m}$ fine fraction contains a large calcite component, which predominantly consists of coccolithophore calcite and some foraminiferal fragments (Drury et al., 2014; Reghellin et al., 2015), as observed elsewhere in the eastern equatorial Pacific (Broecker \& Clark, 2009; Shackleton \& Hall, 1995). Foraminiferal and coccolithophore $\delta^{13} \mathrm{C}$ values predominantly reflect the $\delta^{13} \mathrm{C}$ of the dissolved inorganic carbon $\left(\delta^{13} C_{\text {DIC }}\right)$ in the surrounding seawater (Epstein et al., 1953; Kroopnick, 1985; Margolis et al., 1975). Although foraminiferal and coccolithophore $\delta^{13} \mathrm{C}$ are complicated by vital effects (Bemis et al., 1998; Spero \& Lea, 1993; Ziveri et al., 2003), comparing surface to deep $\delta^{13} \mathrm{C}$ signals can be useful for deconvolving surface productivity from global carbon cycling. Covarying planktic-benthic foraminiferal $\delta^{13} \mathrm{C}$ can indicate a change in the global carbon cycle, whereas antiphase converging/diverging planktic-benthic $\delta^{13} \mathrm{C}$ can result from decreasing/increasing surface water productivity, respectively (Broecker, 1982; Broecker \& Peng, 1982; Hodell \& Woodruff, 1994; Maslin \& Swann, 2005). Planktic-benthic $\delta^{13} \mathrm{C}$ gradient changes driven by the benthic $\delta^{13} \mathrm{C}$ signal can also reflect changes in deep water circulation (Broecker \& Peng, 1982). At Site U1338, the $\sim 1.8-2.5 \%$ orange of benthic-planktic $\Delta \delta^{13} \mathrm{C}$ (Figures $5 \mathrm{a}$ and $5 \mathrm{~b}$ ) reflects the preferential uptake of ${ }^{12} \mathrm{C}$ into organic matter in the surface waters, whereas the $1 \%$ offset of the fine fraction $\delta^{13} \mathrm{C}$ record relative to the planktic $\delta^{13} \mathrm{C}$ (Figures $5 \mathrm{a}-5 \mathrm{c}$ ) reflects large and temporally variable species-specific coccolithophore vital effects (Bolton et al., 2012; Ziveri et al., 2003).

From 8.0 to $7.7 \mathrm{Ma}$, all three $\mathrm{U} 1338 \delta^{13} \mathrm{C}$ records exhibit a broad maximum, followed by a $\sim 1 \%$ o decrease from 7.6 to $6.7 \mathrm{Ma}$ in the foraminiferal $\delta^{13} \mathrm{C}$ records and a $\sim 0.8 \%$ o decrease in the $<63 \mu \mathrm{m} \delta^{13} \mathrm{C}$ record from 7.6 to $7.1 \mathrm{Ma}$ (Figure 5a). This decrease, referred to as the late Miocene Carbon Isotope Shift (LMCIS) is a widespread and globally synchronous event (Bickert et al., 2004; Drury et al., 2017; Haq et al., 1980; Hodell \& Venz-Curtis, 2006; Keigwin, 1979). Prior to and during most of the LMCIS $(\sim 8.0-7.1 \mathrm{Ma})$, the Site U1338 $\delta^{13} \mathrm{C}$ gradients remain comparatively constant: the planktic-benthic $\delta^{13} \mathrm{C}$ gradient is $\sim 2.1 \%$, the fine-benthic $\delta^{13} \mathrm{C}$ gradient is $\sim 0.8 \%$ o, and the planktic-fine $\delta^{13} \mathrm{C}$ gradients is $\sim 1.25 \%$ o (dashed lines, Figure $5 \mathrm{c}$ ). The late Miocene Biogenic Bloom (LMBB), also observed in all oceanic basins, is partially coeval with the LMCIS, suggesting that increased global productivity may have driven the LMCIS (Diester-Haass et al., 2002, 2006; Expedition 320/321 Scientists, 2010; Grant \& Dickens, 2002; Lyle et al., 2012; Lyle \& Baldauf, 2015; Pälike et al., 2010). At Site U1338, sedimentation rates are generally higher between 8.0-4.6 Ma (Figure 2f), supporting the proposed 8.0 to 4.5 Ma timing of the LMBB at Site U1338 (Lyle \& Baldauf, 2015; Reghellin et al., 2015). However, the identical shape of the three U1338 $\delta^{13} \mathrm{C}$ records at the onset of the LMCIS makes it unlikely that this shift was productivity-driven (Figure $5 \mathrm{a}$ ), as productivity would have likely caused a surface-deep $\delta^{13} \mathrm{C}$ divergence (Figure 5). The covariance of all three Site U1338 $\delta^{13} \mathrm{C}$ records provides additional evidence that the LMCIS reflects a global oceanic $\delta^{13} \mathrm{C}$ reservoir shift, further supported by the global extent and synchronous (within 2 kyr) nature of the LMCIS (Drury et al., 2017; Hodell \& Venz-Curtis, 2006; Keigwin, 1979).

After 7.1 Ma, the covariance in the Site U1338 fine-fraction and foraminiferal $\delta^{13} \mathrm{C}$ records breaks down. The planktic-benthic $\delta^{13} \mathrm{C}$ records remain roughly coherent at a gradient of $\sim 2.0-2.2 \%$ o throughout the record. However, the fine fraction $\delta^{13} \mathrm{C}$ record shows a different trend relative to the benthic and planktic $\delta^{13} \mathrm{C}$ records, illustrated by the inverse coherence of the fine-benthic and planktic-fine $\delta^{13} \mathrm{C}$ gradients (respectively left and right axes of Figure 5c). Between 7.1-6.0 and 5.8-4.6 Ma, the fine fraction $\delta^{13} \mathrm{C}$ record increases more dramatically than the foraminiferal $\delta^{13} \mathrm{C}$ (Figures $5 \mathrm{a}-5 \mathrm{c}$ ), curtailing the LMCIS in the fine fraction $\delta^{13} \mathrm{C}$ record, making it shorter and more muted than in the foraminiferal $\delta^{13} \mathrm{C}$ records. The relatively stronger increase in fine fraction $\delta^{13} \mathrm{C}$ relative to the foraminiferal $\delta^{13} \mathrm{C}$ records is further 


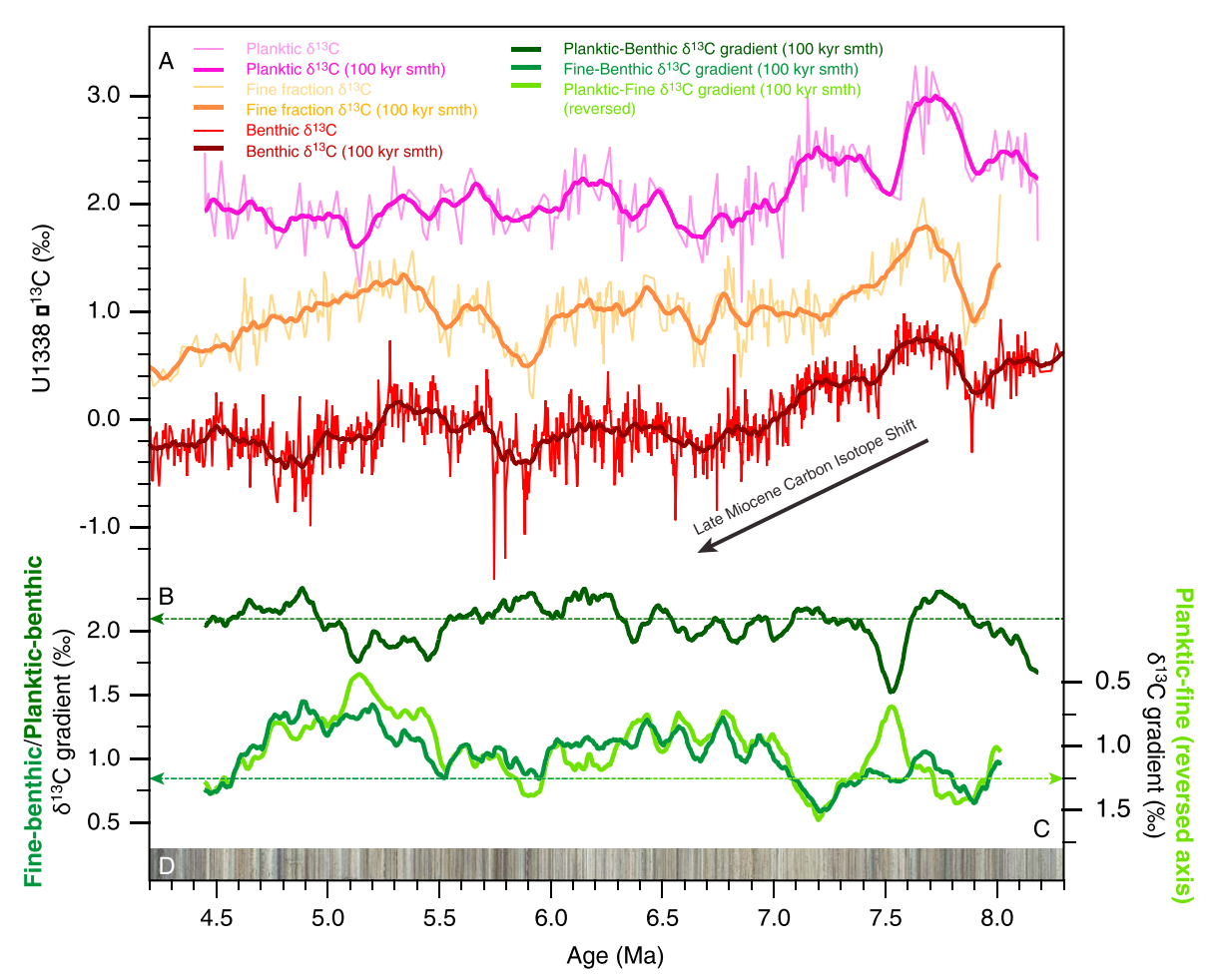

Figure 5. Overview of the Site U1338 (a) $\delta^{13} \mathrm{C}$ records from planktic (pink, this study) and benthic foraminifera (red) (Drury et al., 2016), as well as from the fine fraction $(<63 \mu \mathrm{m})$ (orange) (Reghellin et al., 2015). The late Miocene carbon isotope shift is indicated with a black arrow. The $\delta^{13} \mathrm{C}$ gradients are shown in (b) for the planktic-benthic (dark green) and fine-benthic (green) records and in (c) for the planktic-fine (light green) records, with the axes colored accordingly. The planktic-fine $\delta^{13} \mathrm{C}$ gradient is shown on a reverse axis (right axis) to illustrate the inverse coherence of the planktic-fine $\delta^{13} \mathrm{C}$ gradient and fine-benthic $\delta^{13} \mathrm{C}$ gradient, which is shown on the left axis. Dashed lines show the average $\delta^{13} \mathrm{C}$ gradients during the LMCIS, with the dark green line indicating the LMCIS planktic-benthic $\delta^{13} \mathrm{C}$ gradient $(\sim 2.1 \%$ o) and the graded green-light green line indicating the LMCIS fine-benthic $\delta^{13} \mathrm{C}$ gradient on the left axis $\left(\sim 0.8 \%\right.$ o) and the LMCIS planktic-fine $\delta^{13} \mathrm{C}$ gradient on the right (reversed) axis ( 1.25\%). The spliced core photo is shown in (d) (Wilkens et al., 2013, 2017).

highlighted by a change in the fine-foraminiferal gradients relative to their LMCIS averages (dashed lines, Figure 5c). Grant and Dickens (2002) suggest that increased upwelling and productivity could increase fine fraction $\delta^{13} \mathrm{C}$ (due to ${ }^{12} \mathrm{C}$ uptake in the upper mixed layer) relative to the planktic $\delta^{13} \mathrm{C}$ (deeper mixed layer), which either decrease or remain constant. As such, the increase in the fine-benthic $\delta^{13} \mathrm{C}$ gradient to $\sim 1.1-1.3 \%$ and the decrease in the planktic-fine $\delta^{13} \mathrm{C}$ gradient to $\sim 0.75-1.0 \%$ o between $7.1-6.0$ and 5.8-4.6 Ma (Figure 5c) may indicate that the region experienced enhanced upwelling and productivity. This observation is in line with evidence for increased upwelling between 4.5 and at least $6.5 \mathrm{Ma}$ (Zhang et al., 2017). Increased productivity toward the end of the LMCIS is also supported by slightly increased planktic-benthic $\Delta \delta^{13} \mathrm{C}$ between $6.6-5.5$ and 5.1-4.4 Ma, indicating higher primary productivity in the surface ocean, although slightly converging planktic-benthic $\delta^{13} \mathrm{C}$ records from 5.5 to $5.1 \mathrm{Ma}$ indicate that productivity may have experienced some variability in strength (Figures $5 \mathrm{a}$ and $5 \mathrm{~b}$ ). The fine fraction-foraminiferal $\delta^{13} \mathrm{C}$ gradients may also reflect the onset of coccolithophore vital effects (6.6-4.6 Ma) (Bolton \& Stoll, 2013). Between 8.9 and 8.4 Ma average planktic-nannofossil $\delta^{18} \mathrm{O}$ offsets were $\sim 0.75 \%$ o (Beltran et al., 2014), which is similar to the average planktic-fine fraction offset (range $\sim 0.5-1.0 \%$ ) seen at Site U1338 (Figure 4b). Although the $\delta^{13} \mathrm{C}$ offsets prior to the LMCIS are currently unknown, based on the similarity of the $\delta^{18} \mathrm{O}$ offsets, it is unlikely that vital effects can explain the deviations in the fine fraction foraminiferal $\delta^{13} \mathrm{C}$ gradients. However, further investigations of detailed coccolith vital effects across this interval are required to confirm this. The concurrence of the LMBB and inferred upwelling between 7.1-6.0 and 5.8-4.6 Ma supports the hypothesis that this event was largely driven by upwelling of nutrient-rich waters in the equatorial Pacific Ocean. However, the influence of aeolian dust input cannot be excluded (Diester-Haass et al., 2006; Hovan, 1995), especially 


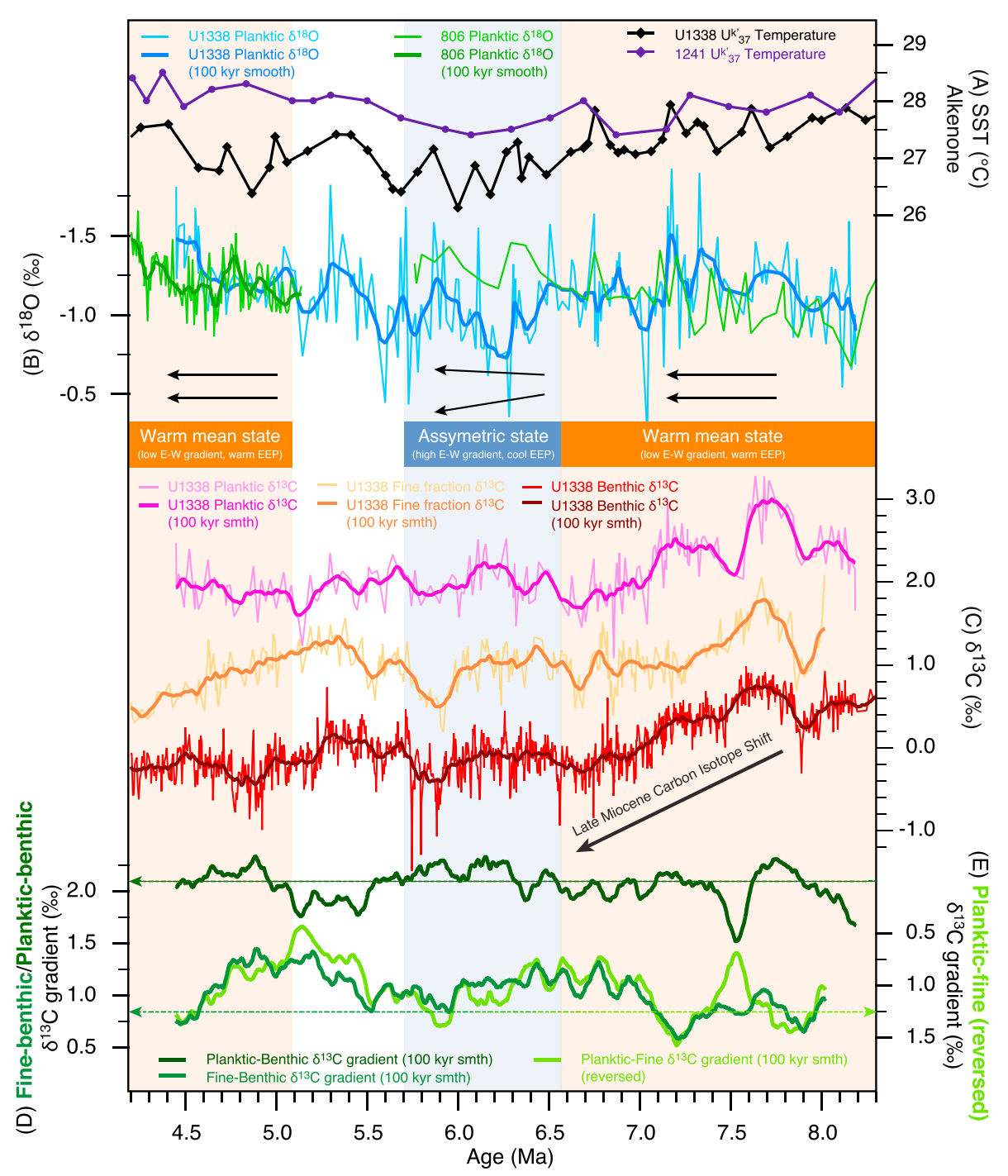

Figure 6. East-west equatorial Pacific mean state overview, with (a) $U_{37}^{k^{\prime}}$-derived SSTs from Sites 1241 and U1338 (Rousselle et al., 2013; Seki et al., 2012), (b) planktic $\delta^{18}$ O records from Sites U1338 (this study) and 806 (Nathan \& Leckie, 2009; Wara et al., 2005), and (c) planktic (this study), fine fraction $(<63 \mu \mathrm{m})$ and benthic $\delta^{13} \mathrm{C}$ records (Drury et al., 2016; Reghellin et al., 2015). The $\delta^{13} \mathrm{C}$ gradients are shown in (d) for the planktic-benthic (dark green) and fine-benthic (green) records and in (e) for the planktic-fine (light green) records. The planktic-fine ${ }^{13} \mathrm{C}$ gradient is shown on a reverse axis (right axis) to illustrate the inverse coherence of the planktic-fine $\delta^{13} \mathrm{C}$ gradient and fine-benthic $\delta^{13} \mathrm{C}$ gradient (left axis). Dashed lines show the average LMCIS $\delta^{13} \mathrm{C}$ gradients: the dark green line = the LMCIS planktic-benthic $\delta^{13} \mathrm{C}$ gradient $(\sim 2.1 \% 0)$; the graded green-light green line = the LMCIS fine-benthic $\delta^{13} \mathrm{C}$ gradient $\left(\sim 0.8 \%\right.$; left axis)/planktic-fine $\delta^{13} \mathrm{C}$ gradient $(\sim 1.25 \%$; right, reversed axis). Orange bars indicate a warm mean state, with low zonal SST gradients and a warm eastern equatorial Pacific (EEP). The blue bar indicates the asymmetric mean state, with increased cross-equatorial gradients and cooling in the EEP.

as the timing of the upwelling implied by the Site $U 1338 \delta^{13} \mathrm{C}$ gradients cannot explain the onset of the LMBB $\sim 8.0 \mathrm{Ma}$.

\subsection{Equatorial Pacific Mean State, Oceanic Gateways, and Global Climate}

\subsubsection{Establishing the Mean State of the Equatorial Pacific}

Records from the western (Site 806), eastern (Site U1338) and far eastern (Site 1241) equatorial Pacific provide a picture of the mean background state of the equatorial Pacific Ocean during the late Miocene to early Pliocene (Figures 1 and 6). Between 8.0 and $6.5 \mathrm{Ma}$, the planktic $\delta^{18} \mathrm{O}$ records from U1338 and 806 agree well (Figure $6 \mathrm{~b}$ ). Considering the similarity of the planktic $\delta^{18} \mathrm{O}$ and $\mathrm{U}_{37}^{\mathrm{k}^{\prime}}$-derived SSTs, the low E-W $\delta^{18} \mathrm{O}$ gradient may indicate consistent mixed layer temperatures across the equatorial Pacific, although 
regional salinity differences cannot be excluded. Warm $U_{37}^{k^{\prime}}$-derived SSTs are also observed at Site U1338 and Site 1241 (Rousselle et al., 2013; Seki et al., 2012) indicating that uniform, warm SSTs dominated the eastern Pacific between 8.0 and $6.8 \mathrm{Ma}$ (Figure $6 \mathrm{a}$ ), and extended to $\sim 1^{\circ} \mathrm{N}$, the location of the modern cold tongue (for backtracked positions, see Pisias et al., 1995 and Pälike et al., 2012). Thus, the observed low equatorial temperature gradient indicates a warm equatorial Pacific mean state from 8.0 to $6.5 \mathrm{Ma}$ (orange bar, Figure 6b).

Between 7.2 and $6.5 \mathrm{Ma}$, the opposing trend in the planktic $\delta^{18} \mathrm{O}$ records, where the Site $806 \delta^{18} \mathrm{O}$ data decreases and the Site U1338 data increases, indicates a gradual transition away from the pervasive warm mean state, although $\mathrm{E}-\mathrm{W} \delta^{18} \mathrm{O}$ gradients remain comparatively low during this time (Figure $6 \mathrm{~b}$ ). The Sites U1338 and 806 planktic $\delta^{18}$ O records diverge by $6.5 \mathrm{Ma}$ (Figure $6 \mathrm{~b}$ ), suggesting an increased E-W mixed layer temperature gradient, although increased salinity at Site U1338 cannot be ruled out. Coincidentally, the eastern equatorial Pacific $\mathrm{U}_{37}^{k^{\prime}}$-derived SSTs diverge, with Site U1338 becoming $\sim 1-2^{\circ} \mathrm{C}$ cooler than Site 1241 after $\sim 6.8 \mathrm{Ma}$ (Rousselle et al., 2013) (Figure 6a), either reflecting the movement of Site 1241 into the EPWP and/or the development of cooler currents at Site U1338 (Figure 1a). The changes observed at Sites 806, U1338, and 1241 indicate an asymmetric equatorial Pacific mean state developed by $6.5 \mathrm{Ma}$ and prevailed until $\sim 5.7 \mathrm{Ma}$ (blue bar, Figure $6 \mathrm{~b}$ ). This asymmetric mean state is characterized by increased E-W mixed layer temperature gradients and cooling in the eastern equatorial Pacific (Figures $6 \mathrm{a}$ and $6 \mathrm{~b}$ ). Following the stratigraphic gap at Site 806, the planktic $\delta^{18}$ O records from Sites U1338 and 806 remain converged between 5.2 and 4.4 Ma, suggesting the return of a pervasive warm mean state, with low equatorial Pacific mixed-layer temperature gradients (orange bar, Figure 6b).

Past late Miocene reconstructions of the equatorial Pacific mean state are contradictory, with studies suggesting 1) a dominant warm state (LaRiviere et al., 2012), 2) oscillations in long-term El Niño-/La Niña-like conditions (Nathan \& Leckie, 2009), or 3) modern equatorial thermal gradients unchanged over the last 12 Myr (Zhang et al., 2014). Data from Sites 1241, U1338 and 806 strongly support a warm mean state between 8.0 and $6.5 \mathrm{Ma}$, an asymmetric mean state, with cooling in the east, between $6.5 \mathrm{Ma}$ and $\sim 5.7 \mathrm{Ma}$, and a warm mean state between $\sim 5.2$ and 4.4 Ma (orange and blue bars, Figure 6). The warm mean state from 8.0 to $6.5 \mathrm{Ma}$ (Figure $6 \mathrm{~b}$ ) is consistent with permanent El Niño-like conditions interpreted from thermocline reconstructions at Site 806 between 9.6 and $6.5 \mathrm{Ma}$ (Nathan \& Leckie, 2009). Increased temperature (Sites 1241-U1338) and $\delta^{18} \mathrm{O}$ (Sites U1338-806) gradients (Figures 6a and 6b) indicate that the equatorial Pacific experienced an asymmetric mean state from 6.5 to $5.7 \mathrm{Ma}$. The timing of the asymmetric mean state agrees well with evidence for a deeper thermocline at Site 806 in the WPWP (Nathan \& Leckie, 2009). The return of a prevailing warm equatorial Pacific mean state between $\sim 5.2$ and 4.4 Ma agrees with other reconstructions indicating widespread warmth during the Pliocene, interpreted as permanent El Niño-like conditions (Dekens et al., 2008; Ford et al., 2012; Groeneveld et al., 2006; Lawrence et al., 2006; Ravelo et al., 2014; Seki et al., 2012; Steph et al., 2006; Wara et al., 2005). Our results therefore support the hypothesis that the equatorial Pacific Ocean oscillates between warm and asymmetric mean states during the late Miocene and early Pliocene. However, the low-resolution nature of records from the western equatorial Pacific limit our observations. As such, future work in the WPWP area, most notably expected from recent IODP Expedition 363 (Rosenthal et al., 2017), will be essential to test our interpretations.

\subsubsection{Role of Oceanic Gateways}

Changes in equatorial Pacific mean state could originate from tectonic/glacio-eustatic changes to the oceanic gateways that enclose the region, namely the Indonesian Throughflow (ITF) in the west, and the Central American Seaway (CAS) in the east. Tectonic and/or glacio-eustatic-driven changes in flow through these gateways may have driven the long-term equatorial mean state changes described here (Figure 6b). Models indicate that changes in the ITF affect equatorial Pacific conditions, with a more open ITF allowing for uniform E-W distribution of warm waters (Cane \& Molnar, 2001; Molnar \& Cane, 2002). The warm mean state, observed between 8.0-6.5 and 5.2-4.4 Ma, may be the result of a relatively unrestricted ITF following global sea level rise driven by a reduction in global ice volume between 7.7-6.7 and 5.2-4.4 Ma, as indicated by deep-sea benthic $\delta^{18} \mathrm{O}$ and ice proximal evidence (Cook et al., 2013; Drury et al., 2016, 2017; Hodell et al., 2001; McKay et al., 2009). Furthermore, coincident with the early Pliocene warm mean state ( 5.2-4.4 Ma), the onset of humid conditions in northwest Australia at $\sim 5.5$ Ma has also been attributed to a more open ITF (Christensen et al., 2017). 
The asymmetric mean state (6.5 to $\sim 5.7 \mathrm{Ma}$ ) may indicate further ITF restriction, coincident with increased benthic $\delta^{18} \mathrm{O}$ and Antarctic cryosphere expansion (Drury et al., 2016, 2017; Nathan \& Leckie, 2009; Ohneiser et al., 2015). The asymmetric mean state could also reflect shoaling of the CAS, which models have shown could result in a shallower eastern equatorial Pacific thermocline (Zhang et al., 2012). CAS shoaling during the middle to late Miocene has been inferred from various deep-sea and continental records (Billups \& Schrag, 2002; Kennett et al., 1985; Lear, Rosenthal, \& Wright, 2003; Lyle, Dadey, \& Farrell, 1995; Montes et al., 2015; Osborne et al., 2014; Savin et al., 1985; Woodruff \& Savin, 1989; Wright et al., 1991).

Changes in ITF restriction and CAS shoaling could explain the changes in the distribution of warmth observed in the equatorial Pacific during the warm-to-asymmetric mean state oscillations. However, models also indicate that the opening and closing of the oceanic gateways enclosing the Pacific Ocean (CAS, ITF, Bering Straits) are not sufficient to explain the amplitude of the observed late Miocene-early Pliocene changes in equatorial Pacific mean state (Brierley \& Fedorov, 2016), and therefore other factors likely contributed.

\subsubsection{Equatorial Mean State and the Late Miocene Global Cooling}

Late Miocene to early Pliocene global climate underwent considerable perturbation. During the Tortonian (11.63-7.46 Ma) and the early Pliocene (5.33-4.4 Ma), globally warm conditions prevailed and meridional thermal gradients were low (Herbert et al., 2016; Pound et al., 2011). However, during the sustained late Miocene global cooling (7.0-5.4 Ma), which was potentially driven by declining atmospheric $p \mathrm{CO}_{2}$ concentrations, SSTs decreased and meridional thermal gradients increased to modern values by $5.4 \mathrm{Ma}$ (Herbert et al., 2016; Pound et al., 2012). Such changes most likely caused considerable perturbations to the atmospheric Hadley and Walker cells, which are key driving forces of the equatorial Pacific upper ocean circulation (Herbert et al., 2016; Lee \& Poulsen, 2006; Pisias et al., 1995), and as such, these shifts may have forced the oscillations in the mean equatorial Pacific climate state observed here (Figure 6b).

A reduction of trade wind intensity across the equatorial Pacific would have established the warm E-W surface ocean conditions seen during the warm mean state between 8.0-6.5 Ma and 5.2-4.4 Ma. The warm mean state between 8.0 and $6.5 \mathrm{Ma}$ (Figure $6 \mathrm{~b}$ ) coincides with reduced latitudinal SST gradients, a weakening and southward shift of the Hadley cell, and weakening of the trade winds (Groeneveld et al., 2017; Herbert et al., 2016). Similarly, after 5.4 Ma, at the end of the late Miocene cooling, SSTs warmed and latitudinal thermal gradients decreased (Herbert et al., 2016), likely resulting in weakening of the Hadley and Walker circulations and the development of a warm equatorial Pacific mean state between 5.2 and $4.4 \mathrm{Ma}$.

The transition to (7.2-6.5 Ma) and dominant asymmetric mean state (6.5-5.7 Ma) (Figure 6), may represent cooling of thermocline waters advected to the eastern equatorial Pacific from subpolar regions during the late Miocene global cooling (7.2-5.4 Ma), when sustained high-latitude surface and deep sea cooling occurred (Drury et al., 2018; Fedorov et al., 2006, 2013; Herbert et al., 2016). The progressive asymmetric E-W gradient and eastern equatorial Pacific cooling from 7.2 to 5.7 Ma (Figure 6) may also reflect an intensification of trade winds, which is supported by increased aeolian deposits in eastern equatorial Pacific to the north of Site U1338 (Hovan, 1995). At present, the eastern equatorial Pacific is dominated by the Eastern Equatorial Cold Tongue (EECT), formed from the cool PCC and some input from the EUC, and partially controlled by the Walker and Hadley circulation (Figure 1a) (Pisias et al., 1995; Rousselle et al., 2013). The development of the asymmetric E-W gradient suggests that the EUC and PCC and the development of the (proto-)EECT first occurred by $\sim 6.5 \mathrm{Ma}$, which is earlier than previously suggested (4.8-4.0 Ma) (Rousselle et al., 2013). Although there is some coincident evidence for increased benthic $\delta^{18} \mathrm{O}$ and cryosphere expansion (Drury et al., 2016, 2017; Ohneiser et al., 2015), our results strongly suggest that the late Miocene experienced significant reorganizations of ocean circulation and climate without large corresponding changes in polar ice sheets. A major reorganization without greatly increased polar ice sheets could indicate that the equatorial Pacific changes were also partly driven by extended sea ice conditions in the southern hemisphere, which models indicated could cause enhanced equatorial Pacific SST gradients during the Plio-Pleistocene (Lee \& Poulsen, 2006). The covariance between the mean state of the equatorial Pacific and high-latitude SSTs further supports that high-latitude changes drove late Miocene global cooling. The asymmetric mean state seen between 6.5 and $~ 5.7$ Ma likely arose because of trade wind intensification and eastern equatorial Pacific thermocline cooling at the peak of the late Miocene cooling, amplified by glacio-eustatic driven ITF restriction and/or increased CAS shoaling. In turn, global precipitation patterns 
may have undergone considerable perturbation in response to the oscillation in equatorial Pacific mean state, late Miocene SST changes (with associated changes in atmospheric and oceanic circulation) (Herbert et al., 2016) and implied decrease in atmospheric $p \mathrm{CO}_{2}$ concentrations (Bolton \& Stoll, 2013; Herbert et al., 2016; Mejía et al., 2017). Such perturbations in global precipitation may have played a role in bringing about the onset of widespread aridity and associated continental $\mathrm{C}_{4}$-grassland expansion during the late Miocene (Cerling et al., 1997; Christensen et al., 2017; Herbert et al., 2016; Lyle et al., 2008; Pagani et al., 1999; Uno et al., 2016).

\section{Conclusions}

Late Miocene-early Pliocene equatorial Pacific planktic foraminifer Mg/Ca-derived SSTs (corrected for past $\mathrm{Mg} / \mathrm{Ca}_{\text {seawater }}$ ) average $\sim 27.8 \pm 1.1^{\circ} \mathrm{C}$ at Site U1338, in line with $\mathrm{U}_{37}^{\mathrm{k}^{\prime}}$ and $\Delta_{47}$-derived SSTs and $3^{\circ} \mathrm{C}$ warmer than modern SSTs at the same position. We observe a $\sim 2^{\circ} \mathrm{C}$ cooling in planktic $\delta^{18} \mathrm{O}$ and $\mathrm{U}_{37^{\prime}}^{\mathrm{k}^{\prime}}$-derived SSTs between 7.2 and 6.1 Ma and $\mathrm{a}+2^{\circ} \mathrm{C}$ warming between 6.1 and 4.4 Ma. The LMCIS occurs as a nearidentical negative $0.8-1 \%$ shift in the fine fraction and foraminiferal $\delta^{13} \mathrm{C}$ records, further confirming that the LMCIS is driven by a change in oceanic reservoir $\delta^{13} \mathrm{C}$. Enhanced sedimentation rates between 8.0 and 4.6 $\mathrm{Ma}$ and fine fraction-foraminiferal $\delta^{13} \mathrm{C}$ gradients suggest that stronger upwelling of nutrient-rich waters and a shallower thermocline in the eastern equatorial Pacific Ocean between 7.1-6.0 Ma and 5.8-4.6 Ma drove high productivity during the LMBB, although an additional, secondary nutrient input through aeolian dust deposits cannot be excluded. A convergence in planktic-benthic $\delta^{13} \mathrm{C}$ between 5.5 and 5.1 Ma also suggests a relative decrease in surface water productivity, indicating the LMBB strength varied with time.

Combined planktic $\delta^{18} \mathrm{O}$ from Sites U1338 and 806 and $\mathrm{U}_{37}^{\mathrm{k}^{\prime}}$-derived SSTs from Sites U1338 and 1241 suggest that a warm mean state dominated the equatorial Pacific between 8.0 and $7.2 \mathrm{Ma}$, which transitioned to an asymmetric mean state by $6.5 \mathrm{Ma}$, and back to a warm mean state by $5.2 \mathrm{Ma}$. The warm states were characterized by low E-W thermal gradients; the asymmetric state was characterized by stronger SST gradients from west to east and cooling in the eastern equatorial Pacific. The younger warm phase (5.2-4.4 Ma) is consistent with prevalent warmth during the Pliocene. The presence of an asymmetric mean state, with cooler SSTs and a shallower thermocline, from 6.5 to $\sim 5.7 \mathrm{Ma}$, is most likely a result of strengthened trade winds due to increased meridional temperature gradients, CAS shoaling and/or further restriction of the ITF through cryosphere expansions. Additionally, increased trade winds would have led to more vigorous surface water circulation and thermocline shoaling, and driven the emergence of a (proto-)EECT $\sim 6.5 \mathrm{Ma}$.

\section{Acknowledgments}

Samples were provided by the Integrated Ocean Drilling Program (IODP) and the IODP Gulf Coast Repository (GCR). The R/V JOIDES Resolution Expedition 320/321 crew, technical staff, and science party members are acknowledged for their effort in collecting the material used in this study. S. Davis is thanked for his help and guidance in the laboratory. T. van Peer is thanked for his advice and D. De Vleeschouwer is thanked for his assistance with TimeOpt. T. Kluge, T. van de Flierdt, and B. Wade are thanked for providing constructive and critical feedback that helped this work. Clara Bolton and an anonymous referee are thanked for their constructive and valuable reviews. A. J. Drury was funded by a Janet Watson studentship from Imperial College London. All data are available at Paleoceanography as a supporting information and on PANGAEA: https://doi.pangaea.de/ 10.1594/PANGAEA.885041.

\section{References}

Alexander, M. A., Blade, I., Newman, M., Lanzante, J. R., Lau, N. C., \& Scott, J. D. (2002). The atmospheric bridge: The influence of ENSO teleconnections on air-sea interaction over the global oceans. Journal of Climate, 15(16), 2205-2231. https://doi.org/10.1175/15200442(2002)015\%3C2205:tabtio\%3E2.0.co;2

Allen, K. A., Hönisch, B., Eggins, S. M., Haynes, L. L., Rosenthal, Y., \& Yu, J. (2016). Trace element proxies for surface ocean conditions: A synthesis of culture calibrations with planktic foraminifera. Geochimica et Cosmochimica Acta, 193, 197-221. https://doi.org/10.1016/j. gca.2016.08.015

Barker, S., Greaves, M., \& Elderfield, H. (2003). A study of cleaning procedures used for foraminiferal Mg/Ca paleothermometry. Geochemistry, Geophysics, Geosystems, 4(9), 8407. https://doi.org/10.1029/2003GC000559

Beltran, C., Rousselle, G., Backman, J., Wade, B. S. S. B. S., \& Sicre, M. A. M. A. A. (2014). Paleoenvironmental conditions for the development of calcareous nannofossil acme during the late Miocene in the Eastern Equatorial Pacific. Paleoceanography, 29, 210-222. https://doi.org/ 10.1002/2013PA002506

Bemis, B. E. B., Spero, H. H. J., Bijma, J., \& Lea, D. D. W. (1998). Reevaluation of the oxygen isotopic composition of planktonic foraminifera: Experimental results and revised paleotemperature equations. Paleoceanography, 13(2), 150-160. https://doi.org/10.1029/98PA00070

Bickert, T., Haug, G. H., \& Tiedemann, R. (2004). Late Neogene benthic stable isotope record of ocean drilling program site 999 : Implications for Caribbean paleoceanography, organic carbon burial, and the Messinian salinity crisis. Paleoceanography, 19, PA1023. https://doi.org/ 10.1029/2002PA000799

Billups, K., \& Schrag, D. P. D. P. (2002). Paleotemperatures and ice volume of the past 27 Myr revisited with paired Mg/Ca and 180/160 measurements on benthic foraminifera. Paleoceanography, 17(1), 1003. https://doi.org/10.1029/2000PA000567

Birch, H., Coxall, H. K., Pearson, P. N., Kroon, D., O'Regan, M., \& Regan, M. O. (2013). Marine micropaleontology planktonic foraminifera stable isotopes and water column structure: Disentangling ecological signals. Marine Micropaleontology, 101(2013), 127-145. https://doi.org/ 10.1016/j.marmicro.2013.02.002

Bolton, C. T., \& Stoll, H. M. (2013). Late Miocene threshold response of marine algae to carbon dioxide limitation. Nature, 500(7464), 558-562. https://doi.org/10.1038/nature12448 
Bolton, C. T., Stoll, H. M., \& Mendez-Vicente, A. (2012). Vital effects in coccolith calcite: Cenozoic climate-pCO(2) drove the diversity of carbon acquisition strategies in coccolithophores? Paleoceanography, 27, PA4204. https://doi.org/10.1029/2012PA002339

Boyle, E. A., \& Keigwin, L. D. (1985). Comparison of Atlantic and Pacific paleochemical records for the last 215,000 years: Changes in deep ocean circulation and chemical inventories. Earth and Planetary Science Letters, 76(1-2), 135-150. https://doi.org/10.1016/0012$821 \times(85) 90154-2$

Brierley, C. M., \& Fedorov, A. V. (2016). Comparing the impacts of Miocene-Pliocene changes in inter-ocean gateways on climate: Central American seaway, Bering Strait, and Indonesia. Earth and Planetary Science Letters, 444, 116-130. https://doi.org/10.1016/j. epsl.2016.03.010

Broecker, W. S. (1982). Glacial to interglacial changes in ocean chemistry. Progress in Oceanography, 11(2), 151-197. https://doi.org/10.1016/ 0079-6611(82)90007-6

Broecker, W., \& Clark, E. (2009). Ratio of coccolith CaCO3 to foraminifera CaCO3 in late Holocene deep sea sediments. Paleoceanography, 24, PA3205. https://doi.org/10.1029/2009PA001731

Broecker, W., and T. Peng (1982). Tracers in the Sea.

Bryden, H., \& Brady, E. (1985). Diagnostic model of the three-dimensional circulation in the upper equatorial Pacific Ocean. Journal of Physical Oceanography, 15(10), 1255-1273. https://doi.org/10.1175/1520-0485(1985)015\%3C1255:DMOTTD\%3E2.0.CO;2

Cane, M. A., \& Molnar, P. (2001). Closing of the Indonesian seaway as a precursor to east African aridification around 3-4 million years ago. Nature, 411(6834), 157-162. https://doi.org/10.1038/35075500

Cerling, T. E., Harris, J. M., MacFadden, B. J., Leakey, M. G., Quade, J., Eisenmann, V., \& Ehleringer, J. R. (1997). Global vegetation change through the Miocene/Pliocene boundary. Nature, 389(6647), 153-158. https://doi.org/10.1038/38229

Christensen, B. A., Renema, W., Henderiks, J., de Vleeschouwer, D., Groeneveld, J., Castañeda, I. S., et al. (2017). Indonesian throughflow drove Australian climate from humid Pliocene to arid Pleistocene. Geophysical Research Letters, 44, 6914. https://doi.org/10.1002/ 2017GL072977

Cook, C. P., van de Flierdt, T., Williams, T., Hemming, S. R., Iwai, M., Kobayashi, M., et al. (2013). Dynamic behaviour of the East Antarctic ice sheet during Pliocene warmth. Nature Geoscience, 6(9), 765-769. https://doi.org/10.1038/ngeo1889

de Villiers, S., Greaves, M., \& Elderfield, H. (2002). An intensity ratio calibration method for the accurate determination of $\mathrm{Mg} / \mathrm{Ca}$ and $\mathrm{Sr} / \mathrm{Ca}$ of marine carbonates by ICP-AES. Geochemistry, Geophysics, Geosystems, 31, 1001. https://doi.org/10.1029/2001GC000169

Dekens, P. S., Lea, D. W., Pak, D. K., \& Spero, H. J. (2002). Core top calibration of $\mathrm{Mg} / \mathrm{Ca}$ in tropical foraminifera: Refining paleotemperature estimation. Geochemistry, Geophysics, Geosystems, 3(4), 1022. https://doi.org/10.1029/2001GC000200

Dekens, P. S., Ravelo, A. C., \& McCarthy, M. D. (2007). Warm upwelling regions in the Pliocene warm period. Paleoceanography, 22, PA3211. https://doi.org/10.1029/2006PA001394

Dekens, P. S., Ravelo, A. C., McCarthy, M. D., \& Edwards, C. A. (2008). A 5 million year comparison of Mg/Ca and alkenone paleothermometers. Geochemistry, Geophysics, Geosystems, 9, Q10001. https://doi.org/10.1029/2007GC001931

Diester-Haass, L., Billups, K., \& Emeis, K. C. (2005). In search of the late Miocene-early Pliocene "biogenic bloom" in the Atlantic Ocean (ocean drilling program sites 982, 925, and 1088). Paleoceanography, 20, PA4001. https://doi.org/10.1029/2005PA001139

Diester-Haass, L., Billups, K., \& Emeis, K. C. (2006). Late Miocene carbon isotope records and marine biological productivity: Was there a (dusty) link? Paleoceanography, 21, PA4216. https://doi.org/10.1029/2006PA001267

Diester-Haass, L., Meyers, P. A., \& Vidal, L. (2002). The late Miocene onset of high productivity in the Benguela current upwelling system as part of a global pattern. Marine Geology, 180(1-4), 87-103. https://doi.org/10.1016/50025-3227(01)00207-9

Drury, A. J., \& John, C. M. (2016). Exploring the potential of clumped isotope thermometry on coccolith-rich sediments as a sea surface temperature proxy. Geochemistry, Geophysics, Geosystems, 17, 4092-4104. https://doi.org/10.1002/2016GC006459

Drury, A. J., John, C. M., \& Shevenell, A. E. (2016). Evaluating climatic response to external radiative forcing during the late Miocene to early Pliocene: New perspectives from eastern equatorial Pacific (IODP U1338) and North Atlantic (ODP 982) locations. Paleoceanography, 31 , 167-184. https://doi.org/10.1002/2015PA002881

Drury, A. J., Lee, G. P., Pennock, G. M., \& John, C. M. (2014). Data report: Late Miocene to early Pliocene coccolithophore and foraminiferal preservation at Site U1338 from scanning electron microscopy. In H. Pälike, et al. (Eds.), Proceedings of the Integrated Ocean Drilling Program (Vol. 320/321, pp. 1-14). Tokyo: Integrated Ocean Drilling Program Management International, Inc.

Drury, A. J., Westerhold, T., Frederichs, T., Tian, J., Wilkens, R., Channell, J. E. T., et al. (2017). Late Miocene climate and time scale reconciliation: Accurate orbital calibration from a deep-sea perspective. Earth and Planetary Science Letters, 475(C), 254-266. https://doi.org/10.1016/j. epsl.2017.07.038

Drury, A. J., Westerhold, T. W., Röhl, U., \& Hodell, D. A. (2018). Reinforcing the North Atlantic Backbone: Revising and extending the composite splice at ODP 982. Climate of the Past, 14. https://doi.org/10.5194/cp-2017-108

Edgar, K. M., Anagnostou, E., Pearson, P. N., \& Foster, G. L. (2015). Assessing the impact of diagenesis on $\delta^{11} \mathrm{~B}, \delta^{13} \mathrm{C}, \delta^{18} \mathrm{O}$, Sr/Ca and B/Ca values in fossil planktic foraminiferal calcite. Geochimica et Cosmochimica Acta, 166, 189-209. https://doi.org/10.1016/j.gca.2015.06.018

Edgar, K. M., Hull, P. M., \& Ezard, T. H. G. (2017). Evolutionary history biases inferences of ecology and environment from $\delta 13 \mathrm{C}$ but not $\delta 180$ values. Nature Communications, 8(1), 1106-1109. https://doi.org/10.1038/s41467-017-01154-7

Elderfield, H., Greaves, M., Barker, S., Hall, I. R., Tripati, A., Ferretti, P., et al. (2010). A record of bottom water temperature and seawater $\delta^{18} \mathrm{O}$ for the Southern Ocean over the past $440 \mathrm{kyr}$ based on $\mathrm{Mg} / \mathrm{Ca}$ of benthic foraminiferal Uvigerina spp. Quaternary Science Reviews, 29(1-2), 160-169. https://doi.org/10.1016/j.quascirev.2009.07.013

Elderfield, H., Vautravers, M., \& Cooper, M. (2002). The relationship between shell size and Mg/Ca, Sr/Ca, delta O-18, and delta C-13 of species of planktonic foraminifera, Geochemistry, Geophysics, Geosystems, 38, 1052. https://doi.org/10.1029/2001GC000194

Elderfield, H., Yu, J., Anand, P., Kiefer, T., \& Nyland, B. (2006). Calibrations for benthic foraminiferal Mg/Ca paleothermometry and the carbonate ion hypothesis. Earth and Planetary Science Letters, 250(3-4), 633-649. https://doi.org/10.1016/J.Epsl.2006.07.041

Epstein, S., Buchsbaum, R., Lowenstam, H. A., \& Urey, H. C. (1953). Revised carbonate-water isotopic temperature scale. Geological Society of America Bulletin, 64(11), 1515-1326. https://doi.org/10.1130/0016-7606(1953)64

Evans, D., Brierley, C., Raymo, M. E., Erez, J., \& Müller, W. (2016). Planktic foraminifera shell chemistry response to seawater chemistry: Pliocene-Pleistocene seawater Mg/Ca, temperature and sea level change. Earth and Planetary Science Letters, 438, 139-148. https://doi. org/10.1016/j.epsl.2016.01.013

Evans, D., Wade, B. S., Henehan, M., Erez, J., \& Müller, W. (2016). Revisiting carbonate chemistry controls on planktic foraminifera Mg/Ca: Implications for sea surface temperature and hydrology shifts over the Paleocene-Eocene thermal maximum and Eocene-Oligocene transition. Climate of the Past, 12(4), 819-835. https://doi.org/10.5194/cp-12-819-2016

Expedition 320/321 Scientists (2010). Site U1338. In H. Pälike, et al. (Eds.), Proceedings of IODP, 320/321: Tokyo (Integrated Ocean Drilling Program Management International, Inc.). https://doi.org/10.2204/iodp.proc.320321.110.2010 
Fedorov, A. V., Brierley, C. M., Lawrence, K. T., Liu, Z., Dekens, P. S., \& Ravelo, A. C. (2013). Patterns and mechanisms of early Pliocene warmth. Nature, 496(7443). https://doi.org/10.1038/nature12003

Fedorov, A. V., Dekens, P. S., McCarthy, M., Ravelo, A. C., DeMenocal, P. B., Barreiro, M., et al. (2006). The Pliocene paradox (mechanisms for a permanent El Niño). Science, 312, 1485-1489. https://doi.org/10.1126/science.1122666

Ford, H. L., Ravelo, A. C., \& Hovan, S. (2012). A deep eastern equatorial Pacific thermocline during the early Pliocene warm period. Earth and Planetary Science Letters, 355-356(2012), 152-161. https://doi.org/10.1016/j.epsl.2012.08.027

Gasperi, J. T., \& Kennett, J. P. (1993). Vertical thermal structure evolution of Miocene surface waters: Western equatorial Pacific DSDP site 289. Marine Micropaleontology, 22(3), 235-254. https://doi.org/10.1016/0377-8398(93)90046-Z

Goddard, L., Mason, S. J., Zebiak, S. E., Ropelewski, C. F., Basher, R., \& Cane, M. A. (2001). Current approaches to seasonal-to-interannual climate predictions. International Journal of Climatology, 21(9), 1111-1152. https://doi.org/10.1002/joc.636

Grant, K. M. K. M., \& Dickens, G. R. G. R. (2002). Coupled productivity and carbon isotope records in the southwest Pacific Ocean during the late Miocene-early Pliocene biogenic bloom. Palaeogeography Palaeoclimatology Palaeoecology, 187(1-2), 61-82. https://doi.org/10.1016/ s0031-0182(02)00508-4

Gray, W. R., Weldeab, S., Lea, D. W., Rosenthal, Y., Gruber, N., Donner, B., \& Fischer, G. (2018). The effects of temperature, salinity, and the carbonate system on $\mathrm{Mg} / \mathrm{Ca}$ in Globigerinoides ruber (white): A global sediment trap calibration. Earth and Planetary Science Letters, 482, 607-620. https://doi.org/10.1016/j.epsl.2017.11.026

Greaves, M., Barker, S., Daunt, C., \& Elderfield, H. (2005). Accuracy, standardization, and interlaboratory calibration standards for foraminiferal Mg/Ca thermometry. Geochemistry, Geophysics, Geosystems, 6, Q02D13. https://doi.org/10.1029/2004GC000790

Groeneveld, J., Henderiks, J., Renema, W., Mchugh, C. M., de Vleeschouwer, D., Christensen, B. A., et al. (2017). Australian shelf sediments reveal shifts in Miocene Southern Hemisphere westerlies. Science Advances, 1-9. https://doi.org/10.1126/sciadv.1602567

Groeneveld, J., Steph, S., Tiedemann, R., Garbe-Schönberg, D., Nürnberg, D., \& Sturm, A. (2006). Pliocene mixed-layer oceanography for site 1241 using combined $\mathrm{Mg} / \mathrm{Ca}$ and $\delta^{18} \mathrm{O}$ analyses of Globigerinoides sacculifer. Proceedings. Ocean Drilling Program. Scientific Results, 202.

Gulick, S. P. S., Shevenell, A. E., Montelli, A., Fernandez, R., Smith, C., Warny, S., et al. (2017). Initiation and long-term instability of the East Antarctic ice sheet. Nature, 552(7684), 225-229. https://doi.org/10.1038/nature25026

Haq, B., Worsley, T., \& Burckle, L. (1980). Late Miocene marine carbon-isotopic shift and synchroneity of some phytoplanktonic biostratigraphic events. Geology, 8(9), 427-431. https://doi.org/10.1130/0091-7613(1980)8\%3C427:LMMCSA\%3E2.0.CO;2

Hayashi, H., Idemitsu, K., Wade, B. S., Idehara, Y., Kimoto, K., Nishi, H., \& Matsui, H. (2013). Middle Miocene to Pleistocene planktonic foraminifera biostratigraphy in the eastern equatorial Pacific Ocean. Paleontological Research, 17(1), 91-109. https://doi.org/10.2517/1342-8144-17.1.91

Herbert, T. D. (2003). 6.15 - Alkenone paleotemperature determinations. In H. D. Holland \& K. K. Turekian (Eds.), Treatise on Geochemistry (pp. 391-432). Oxford: Pergamon. https://doi.org/10.1016/B0-08-043751-6/06115-6

Herbert, T. D., Lawrence, K. T., Tzanova, A., Peterson, L. C., Caballero-Gill, R., \& Kelly, C. S. (2016). Late Miocene global cooling and the rise of modern ecosystems. Nature Geoscience. https://doi.org/10.1038/NGEO2813

Hermoyian, C. S., \& Owen, R. M. (2001). Late miocene-early pliocene biogenic bloom: Evidence from low-productivity regions of the Indian and Atlantic Oceans. Paleoceanography, 16(1), 95-100. https://doi.org/10.1029/2000PA000501

Higgins, J. A., \& Schrag, D. P. (2015). The Mg isotopic composition of Cenozoic seawater-Evidence for a link between Mg-clays, seawater $\mathrm{Mg} / \mathrm{Ca}$, and climate. Earth and Planetary Science Letters, 416, 73-81. https://doi.org/10.1016/j.epsl.2015.01.003

Hodell, D. A., Curtis, J. H., Sierro, F. J., \& Raymo, M. E. (2001). Correlation of late Miocene to early Pliocene sequences between the Mediterranean and North Atlantic. Paleoceanography, 16(2), 164-178. https://doi.org/10.1029/1999PA000487

Hodell, D. A., \& Venz-Curtis, K. A. (2006). Late Neogene history of deepwater ventilation in the Southern Ocean. Geochemistry, Geophysics, Geosystems, 7, Q09001. https://doi.org/10.1029/2005GC001211

Hodell, D. A., \& Woodruff, F. (1994). Variations in the strontium isotopic ratio of seawater during the Miocene: Stratigraphic and geochemical implications. Paleoceanography, 9(3), 405-426. https://doi.org/10.1029/94PA00292

Hönisch, B., Allen, K. A., Lea, D. W., Spero, H. J., Eggins, S. M., Arbuszewski, J., et al. (2013). The influence of salinity on Mg/Ca in planktic foraminifers-Evidence from cultures, core-top sediments and complementary $\delta{ }^{18}$ O. Geochimica et Cosmochimica Acta, 121, 196-213. https://doi.org/10.1016/j.gca.2013.07.028

Hovan, S. A. (1995). Late Cenozoic atmospheric circulation intensity and climatic history recorded by Eolian deposition in the eastern equatorial Pacific Ocean, leg 138. Proceedings. Ocean Drilling Program. Scientific Results, 138, 615-625. https://doi.org/10.2973/odp.proc. sr.138.132.1995

Katz, M. E., Cramer, B. S., Franzese, A., Honisch, B., Miller, K. G., Rosenthal, Y., \& Wright, J. D. (2010). Traditional and emerging geochemical proxies in foraminifera. Journal of Foraminiferal Research, 40(2), 165-192. https://doi.org/10.2113/gsjfr.40.2.165

Keigwin, L. D. (1979). Late Cenozoic stable isotope stratigraphy and paleoceanography of DSDP sites from the east equatorial and central North Pacific Ocean. Earth and Planetary Science Letters, 39(3), 689-690. https://doi.org/10.1215/03616878-2682650

Kennett, J. P., Keller, G., \& Srinivasan, M. S. (1985). Miocene planktonic foraminiferal biogeography and paleoceanographic development of the Indo-Pacific region. In J. P. Kennett (Ed.), The Miocene ocean: Paleoceanography and biogeography. (pp. 197-236).

Khelifi, N., Sarnthein, M., \& Naafs, B. D. A. (2012). Technical note: Late Pliocene age control and composite depths at ODP site 982, revisited. Climate of the Past, 8(1), 79-87. https://doi.org/10.5194/cp-8-79-2012

Kroopnick, P. M. (1985). The distribution of C-13 in the world oceans. Deep-Sea Research Part A: Oceanographic Research Papers, 32(1), 57-84. https://doi.org/10.1016/0198-0149(85)90017-2

LaRiviere, J. P., Ravelo, A. C., Crimmins, A., Dekens, P. S., Ford, H. L., Lyle, M., \& Wara, M. W. (2012). Late Miocene decoupling of oceanic warmth and atmospheric carbon dioxide forcing. Nature, 486(7401), 97-100. https://doi.org/10.1038/nature11200

Laskar, J., Robutel, P., Joutel, F., Gastineau, M., Correia, A. C. M., \& Levrard, B. (2004). A long-term numerical solution for the insolation quantities of the Earth. Astronomy and Astrophysics, 428(1), 261-285. https://doi.org/10.1051/0004-6361:20041335

Lawrence, K. T., Liu, Z., \& Herbert, T. D. (2006). Evolution of the eastern tropical Pacific through Plio-Pleistocene glaciation. Science, 312(5770), 79-83. https://doi.org/10.1126/science.1120395

Lear, C. H., Elderfield, H., \& Wilson, P. A. (2000). Cenozoic deep-sea temperatures and global ice volumes from Mg/Ca in benthic foraminiferal calcite. Science, 287(5451), 269-272. https://doi.org/10.1126/science.287.5451.269

Lear, C. H., Rosenthal, Y., \& Wright, J. D. (2003). The closing of a seaway: Ocean water masses and global climate change. Earth and Planetary Science Letters, 210(3-4), 425-436. https://doi.org/10.1016/s0012-821x(03)00164-x

Lee, S. Y., \& Poulsen, C. J. (2006). Sea ice control of Plio-Pleistocene tropical Pacific climate evolution. Earth and Planetary Science Letters, 248(1-2), 253-262. https://doi.org/10.1016/j.epsl.2006.05.030

Liao, Y., \& Lyle, M. (2014). Late Miocene to Pleistocene sedimentation and sediment transport on the Cocos ridge, eastern tropical Pacific Ocean. Marine Geology, 355, 1-14. https://doi.org/10.1016/j.margeo.2014.05.007 
Locarnini, R. A., Mishonov, A. V., Antonov, J. I., Boyer, T. P., Garcia, H. E., Baranova, O. K., et al. (2010). In S. Levitus (Ed.), World Ocean Atlas 2009, Volume 1: Temperature, NOAA Atlas NESDIS 68 (Vol. 1, p. 184).

Locarnini, R. A., Mishonov, A. V., Antonov, J. I., Boyer, T. P., Garcia, H. E., Baranova, O. K., et al. (2013). World Ocean Atlas 2013, Volume 1 : Temperature. In S. Levitus (Ed.), A. Mishonov (Technical Ed.). NOAA Atlas NESDIS 73 (40 pp.).

Lyle, M., \& Baldauf, J. (2015). Biogenic sediment regimes in the Neogene equatorial Pacific, IODP site U1338: Burial, production, and diatom community. Palaeogeography Palaeoclimatology Palaeoecology, 433, 106-128. https://doi.org/10.1016/j.palaeo.2015.04.001

Lyle, M., Barron, J., Bralower, T. J., Huber, M., Lyle, A. O., Ravelo, A. C., et al. (2008). Pacific Ocean and Cenozoic evolution of climate. Reviews of Geophysics, 46, RG2002. https://doi.org/10.1029/2005RG000190

Lyle, M., Dadey, K. A. K. A., \& Farrell, J. W. (1995). In N. G. Pisias, et al. (Eds.), The late Miocene (11-8 Ma) eastern Pacific carbonate crash: Evidence for reorganization of deep-water circulation by the closure of the Panama Gateway, Proc. Ocean Drill. Program, Sci. Results (Vol. 138, pp. 821-838). https://doi.org/10.2973/odp.proc.sr.138.157.1995

Lyle, M., Lyle, A. O., Gorgas, T., Holbourn, A., Westerhold, T., Hathorne, E. C., et al. (2012). Data report: Raw and normalized elemental data along the site U1338 splice from X-ray fluorescence scanning. In H. Pälike, et al. (Eds.), Proceedings of the Integrated Ocean Drilling Program, Scientific Results 320/321. Tokyo: Integrated Ocean Drilling Program Management International, Inc. https://doi.org/10.2204/iodp. proc.320321.203.2012

Lyle, M. W., Pälike, H., Nishi, H., Raffi, I., Gamage, K., Klaus, A., et al. (2010). In H. Pälike, et al. (Eds.), The Pacific equatorial age transect, IODP expeditions 320 and 321: Building a 50-million-year-long environmental record of the equatorial Pacific Ocean, Sci. Drill (Vol. 9, pp. 4-15). https://doi.org/10.1017/СBO9781107415324.004

Margolis, S. V., Kroopnick, P. M., Goodney, D. E., Dudley, W. C., \& Mahoney, M. E. (1975). Oxygen and carbon isotopes from calcareous nannofossils as paleoceanographic indicators. Science, 189(4202), 555 LP-555557.

Martin, P. A., \& Lea, D. W. (2002). A simple evaluation of cleaning procedures on fossil benthic foraminiferal Mg/Ca. Geochemistry, Geophysics, Geosystems, 3(10), 8401. https://doi.org/10.1029/2001GC000280

Maslin, M. A., \& Swann, G. E. A. A. (2005). Isotopes in marine sediments. In M. J. Leng (Ed.), Isotopes in palaeoenvironmental research (Vol. 0, pp. 227-290). Dordrecht, Netherlands: Springer.

McKay, R., Browne, G., Carter, L., Cowan, E., Dunbar, G., Krissek, L., et al. (2009). The stratigraphic signature of the late Cenozoic Antarctic ice sheets in the Ross embayment. Geological Society of America Bulletin, 121(11-12), 1537-1561. https://doi.org/10.1130/b26540.1

Mejía, L. M., Méndez-Vicente, A., Abrevaya, L., Lawrence, K. T., Ladlow, C., Bolton, C., et al. (2017). A diatom record of $\mathrm{CO}_{2}$ decline since the late Miocene. Earth and Planetary Science Letters, 479, 18-33. https://doi.org/10.1016/j.epsl.2017.08.034

Meyers, S. R. (2014). Astrochron: An R Package for Astrochronology. Retrieved from http://cran.r-project.org/package=astrochron

Meyers, S. R. (2015). The evaluation of eccentricity-related amplitude modulation and bundling in paleoclimate data: An inverse approach for astrochronologic testing and time scale optimization. Paleoceanography, 30, 1625-1640. https://doi.org/10.1002/2015PA002850

Mitchell, N. C., Lyle, M. W., Knappenberger, M. B., \& Liberty, L. M. (2003). Lower Miocene to present stratigraphy of the equatorial Pacific sediment bulge and carbonate dissolution anomalies. Paleoceanography, 18(2), 1038. https://doi.org/10.1029/2002PA000828

Molnar, P., \& Cane, M. A. (2002). El Niño's tropical climate and teleconnections as a blueprint for pre-lce Age climates. Paleoceanography, 17(2), 1021. https://doi.org/10.1029/2001PA000663

Montes, C., Cardona, A., Jaramillo, C., Pardo, A., Silva, J. C., Valencia, V., et al. (2015). Middle Miocene closure of the central American seaway. Science, 348(6231), 226-229.

Moore, J. C., Backman, J., Raffi, I., Nigrini, C., Sanfilippo, A., Pälike, H., \& Lyle, M. (2004). Paleogene tropical Pacific: Clues to circulation, productivity, and plate motion. Paleoceanography, 19, PA3013. https://doi.org/10.1029/2003PA000998

Nathan, S. A., \& Leckie, R. M. (2009). Early history of the Western Pacific Warm Pool during the middle to late Miocene ( 13.2-5.8 Ma): Role of sea-level change and implications for equatorial circulation. Palaeogeography Palaeoclimatology Palaeoecology, 274(3-4), 140-159. https://doi.org/10.1016/j.palaeo.2009.01.007

Ohneiser, C., Florindo, F., Stocchi, P., Roberts, A. P., DeConto, R. M., \& Pollard, D. (2015). Antarctic glacio-eustatic contributions to late Miocene Mediterranean desiccation and reflooding. Nature Communications, 6(1), 8765. https://doi.org/10.1038/ncomms9765

Osborne, A. H., Newkirk, D. R., Groeneveld, J., Martin, E. E., Tiedemann, R., \& Frank, M. (2014). The seawater neodymium and lead isotope record of the final stages of central American seaway closure. Paleoceanography, 29, 715-729. https://doi.org/10.1002/2014PA002676

Pagani, M., Freeman, K. H., \& Arthur, M. A. (1999). Late Miocene atmospheric $\mathrm{CO}_{2}$ concentrations and the expansion of C-4 grasses. Science, 285(5429), 876-879. https://doi.org/10.1126/science.285.5429.876

Pälike, H., Lyle, M., Nishi, H., Raffi, I., Gamage, K., Klaus, A., et al. (2010). Expedition 320/321 summary. In H. Pälike, et al. (Eds.), Proceedings of the Integrated Ocean Drilling Program 320/321. Tokyo: Integrated Ocean Drilling Program Management International, Inc. https://doi.org/ 10.2204/iodp.proc.320321.101.2010

Pälike, H., Lyle, M. W., Nishi, H., Raffi, I., Ridgwell, A., Gamage, K., et al. (2012). A Cenozoic record of the equatorial Pacific carbonate compensation depth. Nature, 488(7413), 609-614. https://doi.org/10.1038/nature11360

Pisias, N. G., Mayer, L. A., Alan, C. M., \& Mix, A. C. (1995). In N. G. Pisias, et al. (Eds.), Paleoceanography of the eastern equatorial Pacific during the Neogene: Synthesis of leg 138 drilling results, Proc. Ocean Drill. Program, Sci. Results, (Vol. 138, pp. 5-21).

Pound, M. J., Haywood, A. M., Salzmann, U., \& Riding, J. B. (2012). Global vegetation dynamics and latitudinal temperature gradients during the Mid to Late Miocene (15.97-5.33 Ma). Earth-Science Reviews, 112(1-2), 1-22. https://doi.org/10.1016/j.earscirev.2012.02.005

Pound, M. J., Haywood, A. M., Salzmann, U., Riding, J. B., Lunt, D. J., \& Hunter, S. J. (2011). A Tortonian (Late Miocene, 11.61-7.25 Ma) global vegetation reconstruction. Palaeogeography Palaeoclimatology Palaeoecology, 300(1-4), 29-45. https://doi.org/10.1016/j.palaeo.2010. 11.029

Ravelo, A. C., Lawrence, K. T., Fedorov, A., \& Ford, H. L. (2014). Comment on a 12-million-year temperature history of the tropical Pacific Ocean Science, 346(6216), 1467 LP-1461467.

Reghellin, D., Coxall, H. K., Dickens, G. R., \& Backman, J. (2015). Carbon and oxygen isotopes of bulk carbonate in sediment deposited beneath the eastern equatorial Pacific over the last 8 million years. Paleoceanography, 30, 1261-1286. https://doi.org/10.1002/2015PA002825

Ries, J. B. (2004). Effect of ambient Mg/Ca ratio on Mg fractionation in calcareous marine invertebrates: A record of the oceanic mg/ca ratio over the Phanerozoic. Geology, 32(11), 981-984. https://doi.org/10.1130/G20851.1

Rohling, E. J., \& Bigg, G. R. (1998). Paleosalinity and d ${ }^{18}$ O: A critical assessment. Journal of Geophysical Research, 103(C1), 1307-1318. https:// doi.org/10.1029/97JC01047

Rosenthal, Y., A. Holbourn, D. Kulhanek, and Expedition 363 Scientists (2017). Expedition 363 preliminary report: Western Pacific warm pool, Proceedings of the International Ocean Discovery Program, 363.

Rosenthal, Y., Lear, C. H., Oppo, D. W., \& Linsley, B. K. (2006). Temperature and carbonate ion effects on Mg/Ca and Sr/Ca ratios in benthic foraminifera: Aragonitic species Hoeglundina elegans. Paleoceanography, 21, PA1007. https://doi.org/10.1029/2005PA001158 
Rousselle, G., Beltran, C., Sicre, M. A., Raffi, I., De Rafelis, M., \& De Rafélis, M. (2013). Changes in sea-surface conditions in the equatorial Pacific during the middle Miocene-Pliocene as inferred from coccolith geochemistry. Earth and Planetary Science Letters, 361(2013), 412-421. https://doi.org/10.1016/j.epsl.2012.11.003

Savin, S. M., Abel, L., Barrera, E., Hodell, D., Kennett, J. P., Murphy, M., et al. (1985). The evolution of Miocene surface and near-surface marine temperatures: Oxygen isotopic evidence. In J. P. Kennett (Ed.), The Miocene ocean: Paleoceanography and biogeography (pp. 49-82)

Schlitzer, R. (2010). Ocean data view 4,

Seki, O., Schmidt, D. N., Schouten, S., Hopmans, E. C., Damste, J. S. S., \& Pancost, R. D. (2012). Paleoceanographic changes in the eastern equatorial Pacific over the last 10 Myr. Paleoceanography, 27, PA3224. https://doi.org/10.1029/2011PA002158

Shackford, J. K., Lyle, M., Wilkens, R., \& Tian, J. (2014). Data report: Raw and normalized elemental data along the site U1335, U1336, and U1337 splices from X-ray fluorescence scanning. Proceedings of the Ocean Drilling Program - Scientific Results, 320/321. https://doi.org/ 10.2204/iodp.proc.320321.216.2014

Shackleton, N. J., \& Hall, M. A. (1995). Stable isotope records in bulk sediments (Leg 138). Proceedings. Ocean Drilling Program. Scientific Results, 138, 797-805

Shackleton, N. J., \& Opdyke, N. D. (1973). Oxygen isotope and palaeomagnetic stratigraphy of equatorial Pacific core V28-238: Oxygen isotope temperatures and ice volume on a $10^{5}$ and $10^{6}$ year scale. Quaternary Research, 55(1), 39-55. https://doi.org/10.1016/00335894(73)90052-5

Spero, H. J., Bijma, J., Lea, D. W., \& Bemis, B. E. (1997). Effect of seawater carbonate concentration on foraminiferal carbon and oxygen isotopes. Nature, 390(6659), 497-500. https://doi.org/10.1038/37333

Spero, H. J., \& Lea, D. W. (1993). Intraspecific stable-isotope variability in the planktic foraminifera Globigerinoides sacculifer: Results from laboratory experiments. Marine Micropaleontology, 22(3), 221-234. https://doi.org/10.1016/0377-8398(93)90045-y

Spero, H. J., \& Williams, D. F. (1988). Extracting environmental information from planktonic foraminiferal delta-C-13 data. Nature, 335(6192), 717-719. https://doi.org/10.1038/335717a0

Spezzaferri, S., Kucera, M., Pearson, P. N., Wade, B. S., Rappo, S., Poole, C. R., et al. (2015). Fossil and genetic evidence for the polyphyletic nature of the Planktonic foraminifera "Globigerinoides", and description of the new genus Trilobatus. PLoS One, 10(5), 1-20. https://doi. org/10.1371/journal.pone.0128108

Steph, S., Tiedemann, R., Groeneveld, J., Sturm, A., \& Nürnberg, D. (2006). Pliocene changes in tropical East Pacific upper ocean stratification: Response to tropical gateways? Proceedings. Ocean Drilling Program. Scientific Results, 202.

Takahashi, T. T., Feely, R. A., Weiss, R. F., Wanninkhof, R. H., Chipman, D. W., \& Sutherland, S. C. (1997). Global air-sea flux of CO 2 : An estimate based on measurements of sea-air pCO(2) difference. Proceedings of the National Academy of Sciences of the United States of America, 94(16), 8292-8299. https://doi.org/10.1073/pnas.94.16.8292

Trenberth, K. E. (1997). The definition of El Nino. Bulletin of the American Meteorological Society, 78(12), 2771-2777. https://doi.org/10.1175/ 1520-0477(1997)078\%3C2771:tdoeno\%3E2.0.co;2

Uno, K. T., Polissar, P. J., Jackson, K. E., \& deMenocal, P. B. (2016). Neogene biomarker record of vegetation change in eastern Africa. Proceedings of the National Academy of Sciences, 113(23), 6355-6363. https://doi.org/10.1073/pnas.1521267113

van der Laan, E., Gaboardi, S., Hilgen, F. J., \& Lourens, L. J. (2005). Regional climate and glacial control on high-resolution oxygen isotope records from Ain el Beida (latest Miocene, northwest Morocco): A cyclostratigraphic analysis in the depth and time domain. Paleoceanography, 20, PA1001. https://doi.org/10.1029/2003PA000995

Van Andel, T. H., Heath, G. R., \& Moore, T. C. (1975). Cenozoic history and paleoceanography of the central equatorial Pacific Ocean. Memoir Geological Society of America, 143, 1-223. https://doi.org/10.1130/MEM143-p1

Wara, M. W., Ravelo, A. C., \& Delaney, M. L. (2005). Permanent El Nino-like conditions during the Pliocene warm period. Science, 309(5735), 758-761. https://doi.org/10.1126/science.1112596

Wilkens, R. H., Dickens, G. R., Tian, J., Backman, J., \& the Expedition 320/321 Scientists (2013). Data report: Revised composite depth scales for Sites U1336, U1337, and U1338. In H. Pälike, et al. (Eds.), Proceedings of the Integrated Ocean Drilling Program 320/321. Tokyo: Integrated Ocean Drilling Program Management International, Inc. https://doi.org/10.2204/iodp.proc.320321.209.2013

Wilkens, R. H., Westerhold, T., Drury, A. J., Lyle, M., Gorgas, T., \& Tian, J. (2017). Revisiting the Ceara rise, equatorial Atlantic Ocean: Isotope stratigraphy of ODP Leg 154 from 0 to 5 Ma. Climate of the Past, 13(7), 779-793. https://doi.org/10.5194/cp-13-779-2017

Woodruff, F., \& Savin, S. M. (1989). Miocene Deepwater oceanography. Paleoceanography, 4(1), 87-140. https://doi.org/10.1029/ PA004i001p00087

Wright, J. D., Miller, K. G., \& Fairbanks, R. G. (1991). Evolution of modern deepwater circulation: Evidence From the late Miocene Southern Ocean. Paleoceanography, 6(2), 275-290. https://doi.org/10.1029/90PA02498

$\mathrm{Yu}, \mathrm{J}$., \& Elderfield, H. (2008). Mg/ca in the benthic foraminifera Cibicidoides wuellerstorfi and Cibicidoides mundulus: Temperature versus carbonate ion saturation. Earth and Planetary Science Letters, 276(1-2), 129-139. https://doi.org/10.1016/j.epsl.2008.09.015

Zeeden, C., Hilgen, F., Westerhold, T., Lourens, L., Röhl, U., \& Bickert, T. (2013). Revised Miocene splice, astronomical tuning and calcareous plankton biochronology of ODP site 926 between 5 and 14.4 Ma. Palaeogeography Palaeoclimatology Palaeoecology, 369, 430-451. https://doi.org/10.1016/j.palaeo.2012.11.009

Zeeden, C., Meyers, S. R., Lourens, L. J., \& Hilgen, F. J. (2015). Testing astronomically tuned age models. Paleoceanography, $30,369-383$. https://doi.org/10.1002/2014PA002762

Zhang, Y. G., Pagani, M., Henderiks, J., \& Ren, H. (2017). A long history of equatorial deep-water upwelling in the Pacific Ocean. Earth and Planetary Science Letters, 467(2017), 1-9. https://doi.org/10.1016/j.epsl.2017.03.016

Zhang, Y. G., Pagani, M., \& Liu, Z. (2014). A 12-million-year temperature history of the tropical Pacific Ocean. Science, 344(6179), 84-87. https:// doi.org/10.1126/science.1246172

Zhang, X., Prange, M., Steph, S., Butzin, M., Krebs, U., Lunt, D. J., et al. (2012). Changes in equatorial Pacific thermocline depth in response to Panamanian seaway closure: Insights from a multi-model study. Earth and Planetary Science Letters, 317-318(2012), 76-84. https://doi.org/ 10.1016/j.epsl.2011.11.028

Ziveri, P., Stoll, H., Probert, I., Klass, C., Geisen, M., Ganssen, G., \& Young, J. (2003). Stable isotope "vital effects" in coccolith calcite. Earth and Planetary Science Letters, 210(1-2), 137-149. https://doi.org/10.1016/s0012-821x(03)00101-8 